\title{
"But what silence! No more gazelles..." Occurrence and extinction of fauna in Lesotho, southern Africa, since the late Pleistocene
}

\author{
Stefan W. Grab ${ }^{\mathrm{a}}$ and David J. Nash ${ }^{\mathrm{a}, \mathrm{b}}$ \\ a School of Geography, Archaeology and Environmental Studies, University of the Witwatersrand, \\ South Africa \\ b School of Environment and Technology, University of Brighton, Lewes Road, Brighton BN2 4GJ, \\ United Kingdom \\ \#
}

Corresponding author:

Stefan Grab

School of Geography, Archaeology and Environmental Studies, University of the Witwatersrand, P/Bag 3, WITS 2050, South Africa 


\begin{abstract}
Understanding the historical dynamics of wildlife distribution and abundance is essential to developing appropriate conservation measures. Here we investigate the occurrence and status of medium- to large-sized fauna (excluding avifauna) for the mountain Kingdom of Lesotho and immediate adjoining regions of South Africa, from the late Pleistocene to the present-day. We provide historical timelines and records of reported medium to large faunal taxa based on: data from eight published archaeological excavations, analyses of several hundred unpublished $19^{\text {th }}$ and $20^{\text {th }}$ century historical documents (including missionary letters, diaries, colonial reports and newspapers), and 58 recent oral history interviews. Vegetation and climate changes through the Holocene are also noted, based on archaeo-botanical records. Through these sources, we record 61 medium to large faunal species for Lesotho and surrounding regions over the past $\sim 21 \mathrm{ka}$, of which only 22 are present today. Some species not previously known to the region are documented (e.g. Temminck's pangolin). Most species were present during the early $19^{\text {th }}$ century, but many regional species extinctions and a major faunal population decline occurred between 1845 and 1850, owing mainly to settler hunting campaigns. Subsequent extinctions have taken place over a wider temporal interval, due to factors including overhunting, human-wildlife conflicts and habitat loss. It seems that some taxa were forced into unsuitable mountain refugia where species eventually succumbed to genetic erosion and/or harsh climatic conditions. Our results increase current understanding of regional faunal and environmental changes, such as the timing of species occurrences and extinction events and processes in Lesotho. Such work adds valuable knowledge to understanding the environmental heritage of the region. Information can be disseminated into wildlife records, national environmental reports, the WWF, the national school environmental educational curriculum and to National Parks and Heritage Sites.
\end{abstract}

Key Words: faunal distribution, faunal extinction, Lesotho, mammals 


\section{Introduction}

Wild fauna have declined dramatically both in number and distribution over the last two centuries, due to factors including human-wildlife conflict (e.g. extermination programmes, disturbance), species exploitation (e.g. bushmeat hunting), habitat depletion and range confinement (e.g. deforestation, desertification, urbanization), pray depletion, biological invasion, climate change and disease (e.g. Zielinski et al., 2005; Davidson et al., 2009; Frick et al., 2010; Grogan et al., 2014; Bellard et al., 2016; Wolf and Ripple, 2016). It is estimated, for example, that mammal species have lost $>68 \%$ of their global historic habitat range; consequently over $50 \%$ of mammal populations are in decline and ca $42 \%$ of terrestrial invertebrate species are threatened with extinction (Davidson et al., 2009; Ceballos et al., 2010, 2017).

To understand the dynamics of contemporary wildlife distribution and abundance, and to develop appropriate conservation mechanisms, it is essential to establish historical contexts of habitats, populations and factors influencing species occurrence over time (Tsujino et al., 2010). To this end, previous studies have documented historical faunal species distributions and occurrence; such as from the forests of Sierra Nevada, USA (early to late $20^{\text {th }}$ century) (Zielinski et al., 2005), the Aragon region of Spain (mid $19^{\text {th }}$ to late $20^{\text {th }}$ century) (Gortázar et al., 1998), the semi-arid savannas of Darfur, Sudan (1799-1998) (Wilson, 2012), and the central deserts of Australia (early to late $20^{\text {th }}$ century) (Burbidge et al., 1988). However, few investigations have provided equivalent detail for mammalian species in southern Africa. The aim of this study is to trace medium- to large-sized faunal occurrence for the mountain Kingdom of Lesotho from the late Pleistocene onwards, and in so doing identify periods of major species-diversity changes and factors that may have influenced such change. Although the fauna of Lesotho have been described in a variety of publications (e.g. Lynch 1994; Avenant 1997, 2006; Skinner and Chimimba 2005; Ambrose 2006; Boshoff and Kerley 2013; Boshoff et al., 2016), we present the first detailed continuous long-term record of faunal occurrence for the region using a combination of archaeological, documentary and oral history records.

The country of Lesotho presents a unique natural laboratory given its relatively small area $\left(30300 \mathrm{~km}^{2}\right.$ ), diverse topography (western lowlands to high mountains and deep valleys) and associated micro-habitats, and its geographic position just west of the Great African Escarpment. Lesotho is thus located at a natural environmental edge - both physically through topographic barriers and ecologically through strong climatic/vegetational gradients. Our particular objectives are to explore this edge effect, and also consider Lesotho as a refugia and island-biogeographic region through time.

\section{Regional setting}

Lesotho is a small independent mountain kingdom, landlocked within South Africa between $28^{\circ}$ and $31^{\circ} \mathrm{S}$, and $27^{\circ}$ and $30^{\circ} \mathrm{E}$ (Fig. 1). Physiographically, the region merges from flat undulating plains with occasional hillocks west of the Caledon River, to the foothills (mountain 
forelands) immediately east of the Caledon River. Further east, the interior of Lesotho hosts several high mountain ranges exceeding 3000m a.s.l., including the Maloti, Thaba Putsoa, Central and Drakensberg Ranges (Fig. 1). The mountains (also referred to as the Lesotho Highlands) are dissected by major fluvial systems (e.g. Senqu and Makhaleng), forming deep gorges. The Great African Escarpment, several hundred metres in height, forms a natural eastern border of Lesotho, known as the Drakensberg. The deep valleys of the interior widen towards the south and east of Lesotho, which today is densely populated.

The vegetation in the western lowlands is typically Highlands Sourveld, while that across the mountain ranges is Themeda-Festuca Alpine Veld. Afro-alpine Grasslands (Merxmuellera drakensbergensis - Festuca caprina) and marginal periglacial conditions occur above ca 2900m elevation (Du Preez and Bredenkamp, 1991; Kay et al., 1993; Grab and Knight, 2016). The contemporary climate is semi-arid to sub-humid, with mean annual rainfall varying from $<740 \mathrm{~mm}$ in the western and southwestern lowlands, to $>1600 \mathrm{~mm}$ in the northeastern highlands (Sene et al., 1998; Hydén, 2002). The climate is distinctly seasonal with $80 \%$ of precipitation falling during the austral summer months (October-March) and less than $10 \%$ during winter (May-August). Summer temperatures in the lowlands may regularly exceed $30^{\circ} \mathrm{C}$ but seldom reach $20^{\circ} \mathrm{C}$ above $3000 \mathrm{~m}$ elevation. Frost is widespread across the region from mid-May to mid-September. Occasional snowfalls are possible in the Highlands each year, but have become infrequent in the lowlands (now < 30\% annual occurrence in the lowlands and ca 11 light snowfall events per annum above 3000m a.s.1.)(Grab and Nash, 2010; Grab et al., 2017).

\section{Materials and methods}

To establish faunal occurrences and histories in Lesotho and surrounding regions, the collation of data from three primary sources was required; namely, published results from past archaeological excavations (spanning the late Pleistocene to late Holocene), unpublished historical documentary records (ca AD 1830 to 1930) and oral histories/modern texts and personal observations (ca AD 1930 to present).

\subsection{Archaeological records}

Abundant faunal records are preserved in accumulated sedimentary sequences in numerous rock shelters and open-air sites throughout Lesotho and adjacent regions. These records have been examined in considerable detail and thus offer an opportunity to establish regional faunal occurrence during the late Quaternary (see Engela, 1995; Plug and Engela, 1992; Plug, 1997; Wadley, 2000; Plug et al., 2003, Plug and Mitchell, 2008; Arthur et al., 2018; Badenhorst et al., 2019). Several primary excavated archaeological localities have yielded a wide species variety (ca 50+) of medium- to large-sized fauna from ca 20000 to $1000 \mathrm{BP}$; these include sites in the western mountain forelands (Liphofung, Muela [see Plug 1997], Rose Cottage [see Plug and Engela, 1992; Engela, 1995; Wadley, 2000], Tloutle, Leqhetsoana and upper Puthiatsana River valley sites [see Arthur et al., 2018]), southern mountain foreland (Bolahla [see Plug, 1997]) and mountain valleys (Likoaeng [see Plug et al., 2003], Sehonghong [see Plug and Mitchell, 2008], Moshebi's Shelter [see Badenhorst et al., 2019]) (Fig. 1). Apart from 
Rose Cottage, which is immediately west of the Caledon River/Lesotho border, all other sites are located in Lesotho at elevations ranging between ca 1650 to $2286 \mathrm{~m}$ a.s.l. This offers an opportunity to compare past faunal assemblages (and possible occurrences) in a diverse habitat including relatively flat to undulating grasslands in western and southern Lesotho (forelands), to the more mountainous central interior and eastern regions of Lesotho (highlands). However, the entire region offers diversity in grasslands, shrublands and rocky outcrops. Previously, riverine thickets and woodlands would have aligned the many stream and river valley floors (e.g. Grab et al., 2005; Stewart and Mitchell, 2018).

While archaeological evidence provides important insights into species occurrence, the interpretation of species data requires some caution. For instance, site assemblages depend on dietary preferences of hunter-gatherer communities, or the extent to which (quantity/distance) faunal remains were imported (cf. Badenhorst et al., 2019). In addition, the absence of some species at excavation sites does not necessarily imply their temporal/spatial absence - as this may be influenced by selective preference for certain species (e.g. hunting preferences, belief systems etc.), occupation histories, species behavioural patterns (e.g. migration patterns, nocturnal habits) and poor/disturbed site preservation (e.g. Discamps et al., 2011). Similarly, high species counts at multiple sites may not always imply species abundance. Notwithstanding the above cautionary outline, ethnographic studies (e.g. Bunn, 1982) have shown that modern foragers usually select prey that reflect the faunal landscape. Hence, the occurrence of specific fauna (as recorded from archaeological sites) during given time periods should provide a reasonably good indication to their presence in the broader region.

\subsection{Historical documentary records}

Documentary records from early settlers and travellers in the Lesotho region include detailed accounts of the environment, weather/climate and wild fauna - in some cases providing long lists of all fauna sighted at a given place and time. Historical collections relevant to the period 1830 to 1900 were scrutinized in archives in Lesotho and the UK for such information. The most informative of these were outbound reports and letters sent from various mission stations established in and around Lesotho from the 1820s onwards (Fig. 2). Several missionaries took a particular interest in nature and wildlife and thus provided valuable detail through their letters; most notably T. Arbousset and E. Casalis (of the Paris Evangelical Missionary Society; PEMS). Further, eight PEMS missionaries (T. Arbousset, E. Casalis, F. Daumas, F. Maeder, C. Gosselin, P. Germond, J. Gêrard, D.F. Ellenberger) spent 27 or more years in Lesotho and/or the surrounding regions during the $19^{\text {th }}$ century, and provide knowledgeable and well-informed accounts on faunal changes through time, and also insights into the dynamics of such changes. Detailed diaries for the region include those of Dr A. Smith (for the years 1834-1836), L. Cochet (1845-1900) and Sir G. Lagden (1884-1900), the Resident Commissioner for Basutoland. Finally, a host of published sources were consulted, including books reflecting on personal accounts of life and travel in Lesotho, and newspapers such as the Sesotho-language periodical Leselinyana la Lesotho - first published monthly in 1863 and expanded to a fortnightly edition in 1885. Documents were accessed and scrutinized at the Morija Mueseum and Archives, National Archives and National University of Lesotho library (Lesotho); School of Oriental and African Studies (SOAS, University of London, UK); and Bodleian Library of 
Commonwealth and African Studies at Rhodes House (University of Oxford, UK). Each source was read in chronological order and all wildlife, environmental and associated relevant information recorded verbatim. Information from French/Sesotho texts was translated to English as appropriate.

Documentary records are particularly valuable as they usually provide specific spatial and temporal details on animal sightings, and may even be accompanied by sketches of wildlife encounters (Fig. 3). However, such records are not without limitations. For example, some years may pass without any reference to wildlife, especially during periods of severe drought or war. Reporting of wildlife is not spatially uniform across the region, but often from only a few key mission stations or from a particular route taken by a traveller/explorer. Species' charisma determines likely over- or under-reporting of particular mammals (c.f. Monsarrat and Kerley, 2018), with small, shy, rare, cryptic and nocturnal species likely underreported or not reported at all. The written context also needs to be well- understood; hence, whenever possible, we triangulate across multiple sources to compare and verify results. Places named after wild fauna have been widely used as evidence (through critical analysis) for the former occurrence of the named species, such as wolves and beavers in the UK (Aybes and Yalden, 1995; Hough, 2008), pronghorn antelope and mountain lion in southwestern USA (Lett, 1970) and bears in southern India (Si and Agnihotri, 2014). To this end, many villages and geographic locations (e.g. mountains, mountain passes, districts etc.) in Lesotho are named after specific fauna (Table 1). The naming of places after wild animals originated from the $18^{\text {th }}$ to earlier $20^{\text {th }}$ centuries, which suggests considerable cultural attachment. According to informal discussions with local inhabitants, in most cases, such names represent an association with the specific animal at a given place or within a given region of Lesotho, and are thus of symbolic (rather than ritualistic) importance to a given place. In fact, most names mean 'place of' + species (e.g. Mangaung; place of the Cheetah). Notably, all wild animal place names in the Lesotho region have either been recorded in the archaeological, documentary or oral records, while many species typical to southern Africa but not the Lesotho region (e.g. elephant; rhinoceros; giraffe) have not been used as place names. We provide a list and geographic distribution of wild animal place names and use these to complement the recent oral and documentary records (Table 1).

\subsection{Oral historical records}

Oral histories provide valuable supplementary information to written records or can assist to fill gaps where such records are unavailable (Hofmeyer, 1993). In 2008, with full ethics clearance from the University of the Witwatersrand, we undertook 58 interviews across 44 villages in Lesotho (Fig. 4), focusing on recent wild animal sightings and the memories of wild fauna. The interviews were conducted in Sesotho after permission was granted from local village chiefs. The chiefs advised on who in each village to interview. Prior oral consent was obtained from all participants to the study. Respondents were elderly people between the ages of 60 and 106 years, mostly (68\%) men who were herders in their youth, but also included several school teachers, traditional healers and women. Traditional healers provided evidence of wild animal skins and skulls that had been hunted for medicinal and other traditional 
purposes during recent years. The interview process was in an open-ended 'story telling' style. Each interview culminated with an identification of mammals from a chart based on Stuart and Stuart (2001). We undertook an additional 16 ad hoc informal discussions with young herders while travelling between villages - these too, identified contemporary wild fauna from the chart presented to them. These records were used in conjunction with a range of $20^{\text {th }}$ century and more recent texts focussing on the wild fauna of Lesotho and adjoining eastern Free State of South Africa - most notably the National Environment Secretariat (2000) report and Ambrose (2006). All interview results were critically scrutinized and those that indicated an element of exaggeration or impossibility were labelled as 'spoilt' and discarded (9\% of results).

\section{Results}

\subsection{The archaeological record (late Pleistocene to early $19^{\text {th }}$ century)}

Faunal remains predating ca 21000 BP (pre Last Glacial Maximum) in Lesotho are limited and of lowest density (Plug and Mitchell, 2008), in part due to poor preservation. Species variety was likely minimal during the Last Glacial Maximum (Plug, 1997) when the climate was distinctly cold and marginally glacial at highest altitudes (Mills et al., 2009, 2012). Smaller bovids were at this time poorly represented, and several larger varieties (long-horn [giant] buffalo; giant hartebeest; giant Cape horse) became extinct by ca 10000 BP (Cooke, 1963; Klein, 1974). Large to medium sized bovids are well represented during the Pleistocene/Holocene transition (ca 12000 to 10000 BP), but carnivores are only occasionally documented during this time (Table 2). These findings may, in part, reflect variability in preservation between larger and smaller fauna over longer periods of time. Bond's springbok is thought to have survived until shortly after ca $7500 \mathrm{BP}$, before it too became extinct (Brown and Verhagen, 1985); coinciding with a time of rapid and pronounced regional cooling $\left(3-4^{\circ} \mathrm{C}\right)$ and aridification (ca 8600 to $8000 \mathrm{BP}$ ) (Smith et al., 2002; Grab et al., 2005; Fitchett et al., 2017). It is unlikely that these bovids were preferentially hunted over other species that survived beyond the early Holocene, and thus their demise was likely due to climatic and associated ecological/ environmental change (Klein and Cruz-Uribe, 1987; Plug and Engela, 1992; Mitchell et al., 1998).

The time leading up to ca $12000 \mathrm{BP}$ was relatively wet and supported dense riparian vegetation within Lesotho valleys (Grab et al., 2005; Stewart and Mitchell, 2018), offering refuge to bushbuck at ca 13200 to 12200 BP in eastern Lesotho (Mitchell 1996); a bovid not since recorded in the country. The Pleistocene-Holocene transition was associated with warmer conditions, plant diversification and the consequent proliferation of fauna (Plug 1997; Smith et al., 2002; Stewart and Mitchell, 2018). Smaller bovids (common [grey] duiker; steenbok; grey rhebok; klipspringer), previously only recorded from the foothills and mountain valleys, are recorded for the first time in the western lowlands by ca 10000 to $8000 \mathrm{BP}$. In addition, blue duiker, greater kudu and vervet monkeys are recorded for the first time in Lesotho shortly after 9000 BP (Mitchell et al., 1998). 
The mid to late Holocene in Lesotho was marked by alternating wetter/warmer and drier/cooler episodes (Marker, 1995; Grab et al., 2005; Fitchett et al., 2016, 2017; Stewart and Mitchell, 2018), which may in part account for some of the observed spatial and temporal changes in species occurrence and distribution (lowlands vs highland valleys) (Table 2). Several species have a widespread and continued presence across Lesotho throughout the Holocene (chacama baboon; rock hyrax; warthog; steenbok; grey rhebok; mountain reedbuck; klipspringer; black wildebeest; red hartebeest; blesbok; springbok; common eland; hare; southern African porcupine; genet/weasel; black-backed jackal). Smaller felidae (caracal and African wild cat) are more regularly recorded from the mid-Holocene onwards. Leopard are commonly recorded throughout Lesotho, particularly from the mid-Holocene onwards, yet lion and cheetah are noticeably absent. Lion were probably avoided by the San, hence a lack of any other archaeological record, while cheetah were likely only occasional visitors, as seems to have been the case with African wild dog (only one record from eastern Lesotho during the late Holocene). Spotted hyaena are absent from Lesotho archaeological records and brown hyaena seem to make a stronger appearance towards the late Holocene (i.e. last ca 3000 years) in both lowland and highland regions. Other carnivores recorded for the first time during the late Holocene include the Cape fox and aardwolf. Notably, both these carnivores generally thrive best in relatively open or dry conditions with sparse vegetation cover (Von Richter, 1972; Blaum et al., 2007), which is in strong agreement with drier conditions that set in after ca 3000 BP (Scott and Nyakale, 2002; Scott et al., 2012).

A few further noteworthy observations can be made on faunal occurrence during the Holocene. Black wildebeest were apparently present throughout Lesotho from the Late Pleistocene until late Holocene (see Carter, 1978; Mitchell, 1993; Plug, 1993). Records of blue wildebeest, however, are more sporadic, with the species likely absent during the colder Pleistocene period and between ca 5000 and $3000 \mathrm{BP}$. At other times (ca 10000 to $5000 \mathrm{BP}$ and during the last 3000 years), the two subspecies co-existed in the region; this being possible through their differential niche occupation at family group and herd levels, rather than between species (Codron and Brink, 2007). It seems likely that the black wildebeest was not only the more common of the two sub-species but adapted better to climate/environmental fluctuations through the Holocene. Interestingly, San rock art in Lesotho only portrays black wildebeest (Vinnicombe, 1976). Impala, a widespread and common savannah antelope to southern Africa in recent times (Nersting and Arctander, 2001), is only recorded from the Lesotho western lowlands during the last ca 3000 years and were thus likely absent from such interior plateau regions for most of the Holocene. The nocturnal insectivorous aardvark (antbear) and aardwolf are recorded from the Lesotho highlands regions during the last ca 5000 years, but not from earlier Holocene times. In contrast, Temminck's pangolin is absent from all Lesotho archaeological sites with faunal assemblages, but an isolated late Holocene (ca $2300 \mathrm{BP}$ ) record exists from Riversmead, $80 \mathrm{~km}$ south of Lesotho (Klein, 1979). It is thus possible that pangolin were present in parts of Lesotho during recent millennia, but for one or more reasons not part of archaeo-faunal essemblages. The likely occurrence of plains zebra and bushpig in the highlands during the late Holocene (ca last 1000 years) is supported by archaeological finds from Moshebi's shelter (Badenhorst et al., 2019). 
The total number of individual mammal species identified from archaeological excavations in the Lesotho region gradually increases through the Holocene: ca 14000 to $10000 \mathrm{BP}=29$; ca 10000 to $5000 \mathrm{BP}=31$; ca 5000 to $3000 \mathrm{BP}=36$; last ca 3000 years $=43$. This trend may be related to the presence of possibly a greater number of later- than earlier-Holocene archaeological sites, and/or a function of improved faunal preservation and associated better identification with decreasing age. Should this indeed be the case, then the earlier Holocene faunal records are under-represented. However, the records presented here could also reflect gradual mammalian diversification through the Holocene as climate/environmental conditions generally progressed from the cold post-glacial early- Holocene to the warmer/wetter midHolocene and climatically variable late-Holocene (Scott et al., 2012).

\subsection{The documentary record ( $A D$ 1830-1900)}

4.2.1. Accounts of species presence / absence

When the French missionaries first established a written record in the Lesotho region (1830s), the area was teeming with wildlife. Massive herds of black wildebeest, springbok, plains zebra and red hartebeest thrived along the grasslands to the west and east of the Caledon River and many other species were reported (Casalis, 1833; Lesinyana la Lesotho, 1884, vol 6). This is reflected in comments made by missionaries:

"It is difficult, if not impossible to imagine the enormous number of wild animals who live in the deserts of Africa without seeing it with one's own eyes"

(PEMS AA FBN1 12. Casalis, E., Philippolis. 31 July 1833)

"I saw another huge herd of springbok. There were so many! One couldn't even begin to count them. I could see them as far as my eyes allowed..."

(Referring back to 1839; Leselinyana la Lesotho, 1884, vol 6)

During the earliest years of settlement, missionaries had a difficult time with wild animals, particularly carnivores (primarily lion and hyaena [one or both of spotted/brown hyaena]). This was possibly owing to these species being attracted to homesteads where livestock were kept and the missionary's inexperience in managing such situations. Casalis writes on 22 July 1833 that 'the wild animals worried us a lot last night......the edges of the Caledon are infested with terrible lions......they devoured one of my oxen' (PEMS AA FBN1 12. Casalis, E., Philippolis. 31 July 1833). However, within a few years the missionaries either had better control over the situation or the numbers of carnivore visitations had subsided, as Arbousset reports from Morija in 1835 that 'the wild animals don't bother us as much as last year, however lately they devoured two of our most beautiful mares' (PEMS AA FBN1 20. Arbousset, Th. Morija. 3 December 1835). Bovids were also a problem as they damaged and depleted the Basotho and missionary vegetable gardens, and black wildebeest were known to lead cattle away from homesteads (Lesinyana la Lesotho, 1884, vol 6).

The first mention of reduced animal numbers in the foothills is in 1840, when Arbousset, on a hunt along the north-western foothills of the Maloti Mountains (Maoa-mafubelu - today known as the Mamafubelu catchment), reports that some years previously common eland numbers 
'were phenomenal in this region' but none were to be seen on this outing (Arbousset, 1991). The eland was hunted extensively; consequently, as noted by the missionaries, these antelope became skittish and by 1846 had retreated into the mountains.

"We ourselves have seen it [eland] disappear within these few years before the tribes of Basutos, and seek refuge in the mountains, for which it has decided preference."

(Arbousset and Daumas, 1846, p.4)

However, the grasslands away from the mountain front still hosted substantial wildlife in 1842 , at least on a seasonal basis. Maeder describes that 'the game travels through the field in extraordinary numbers', in particular 'couagga' [Equus quagga], red hartebeest, black wildebeest, springbok and other bovids (PEMS AA FBN 69. Maeder, F., Bérseba. 1 October 1842).

By 1856, the mimosa forests from the Caledon River to the Madder (now Modder) River (ca $200 \mathrm{~km}$ to the west of Lesotho) had been deforested and replaced by pastures. Consequently, large game (Quaggas, wildebeest, springbok and other antelope, along with lion and hyaena) had for the most part disappeared, while domestic livestock (sheep, goats, oxen, horses and mules) increased (PEMS AA FBN 166. Lemue, P., Carmel. 10 November 1856). The situation is reiterated by the missionary P. Lemue five years later:

At the return of spring my wife and I set off across the plains which before we called the jagt veld [hunting ground], land of game. But what silence! What emptiness! No more gazelles, no more roaring lions, not even the yelping of the Jackal to break the monotony of the desert.

(PEMS AA FBN 194. Lemue, P., Carmel. 28 October 1861)

By the mid-1870s, game had 'withdrawn itself to the mountains' and it had been four years since the last lion had been killed near Makwae (i.e. in 1872; Germond 1967, citing Preen). Preen reports game was still in abundance in the major valleys of central Lesotho, such as the Maletsunyane, where he counted a herd of 14 red hartebeest in 1878. According to local Basotho, lion were still in this valley at the time but Preen found this impossible to believe (Germond 1967, citing Preen). Jacottet reports from Thaba Bosiu in 1893 that:

We (that is my guide Nakati and myself) have seen neither lions nor crocodiles, nor hippopotami, with the exception of a few leopards, there are no more wild animals in the Maloti, they vanished years ago.

(Germond 1967, p423)

Yet, a few years later (in 1897) cattle herders saw a lion in the vicinity of Likolobeng (just east of Roma) (Leselinyana la Lesotho, 15 June 1897, p4) - this was the last reported and confirmed sighting or incident of a wild lion in the country (Fig. 5). This newspaper article also mentions that leopard were killed in 1895 and 1896. These accounts demonstrate some degree of uncertainty as to the exact times of regional species' extinctions, given isolated vagrants venturing into remote mountainous valleys. In addition, given the remoteness of Lesotho 
mountain communities, it is likely that other wildlife encounters have gone unreported. Nevertheless, these accounts indicate that for several species, there would have been a period of uncertainty as to their continued existence in the region as numbers declined and coexistence with people became increasingly difficult.

\subsubsection{Regional mammal disappearance / extinctions}

Based on documentary evidence, it is possible to temporally track larger mammalian species occurrence and regional extinctions through the $19^{\text {th }}$ century (Fig. 5). Three primary periods of regional extinction are identified: a) the period prior to European settlement (pre AD 1820) when vervet monkeys, common hippopotamus and Nile crocodile became extinct along the Caledon River valley; b) during the 1840s when many larger mammals still common during the early 1830s, were last sighted (e.g. African wild dog, cheetah, spotted hyaena, Quagga, blue wildebeest, common reedbuck); and c) the late 1850 s to 1860 s when springbok, black wildebeest and blesbok were last reported. This presents an extraordinary regional mammalian population crash over a period of only three decades, indicating also a collapse in mass migrations. Here we highlight a few examples of regional species extinctions.

Although vervet monkeys were locally present through much of the mid to late Holocene, the species must have disappeared from the Lesotho region a considerable time before missionaries arrived as by 1836 Arbousset reports that the 'Basoutos only know this [baboon] species of monkey' (PEMS AA FBN1 25. Arbousset, Th. Journal de notre voyage au nord du pays des Bassoutos. Dans le mois de Mars, Avril et de Mai 1836. No III). In 1840, Arbousset (1991) describes the Thupa-Kubu River valley (see Fig. 1), which translated is 'Wood of the Hippopotamus'. The name, together with the testimony of people who spoke to Arbousset, indicate the occurrence of hippopotamus in the region shortly before the first missionaries arrived - possibly the last hippopotamus disappeared from the Caledon and adjoining tributaries between AD 1800-1820.

Nile crocodile had already disappeared by the time missionaries arrived in the area, but local inhabitants provided vivid descriptions of reptiles in the waters of the Caledon River:

With regards to the crocodiles, the natives tell us that there are two species in the little Caledon. One is the size of a young calf, according to the comparison of the natives. The other, they say, has a body so long that it forms a small dam in the river when it puts itself across it. The Bassoutos call the first species of these reptiles Kuene and the second Lefitue. They are very afraid of them both.

(PEMS AA FBN1 25. Arbousset, Th. Journal de notre voyage au nord du pays des Bassoutos. Dans le mois de Mars, Avril et de Mai 1836. No 1.)

Reference to 'Kuene' (French spelling) stems from the indigenous language reference to 'koena' or 'kwena', meaning crocodile. Given that reptiles referred to here belong to a folktaxonomy of mythological 'snakes' that live in rivers, these may not necessarily reflect a literal occurrence of such 'creatures'. However, the settlement of Likoeneng (meaning: 'place of the crocodile') (Table 1) is located near the Makhaleng River in southern Lesotho, which might 
suggest that these reptiles possibly inhabited the larger tributaries flowing into the Caledon and Senqu (Orange) Rivers before the period of European colonization.

Soon after Arbousset's arrival in the region (1836), he lists a multitude of mammalian species, amongst which are 'couagya' and plains zebra, two Equus species identified as different in their temperament. The San hunter-gatherers also distinguished these two Equus sub-species through their rock art. By 1846, Arbousset and Daumas confirm the occurrence of Quagga but absence of zebra in western Lesotho:

"As to the quaggas which were killed, they were grazing among a great number of others, but there did not appear to be a single zebra in the whole herd; it is the fact, moreover, that the zebra is not found either among the Basutos or the Mantetis, while the quagga is very common in their district, a new and conclusive proof that the latter is not the female of the former, as was for a long time believed."

(Arbousset and Daumas, 1968, p.86)

However, it is likely that the quagga became regionally extinct in the mid-19 ${ }^{\text {th }}$ century given that the last sighting was reported by Arbousset in 1847. A decade later in 1856, the once 'vast herds' (1833) of springbok, which in 1842 still migrated into the region in 'extraordinary numbers', were reported for the last time in Lesotho by Fredoux.

Members of the genus Hippotragus (roan antelope and/or blue buck) were present in the area during various times through the Holocene, including late Holocene (Plug and Engela, 1992), and are depicted on San rock art panels in the region (Loubser et al., 1990) It is widely assumed that blue buck, which were possibly confined to the Cape Floristic Region (Faith and Thompson, 2013), became extinct by the late $18^{\text {th }}$ century, as there are no confirmed sighting since then (Broom, 1949; Kerley et al., 2009; Themudo and Campos, 2017). However, Colahan (1990) presents a case (based on habitat preference) that the sighting of alleged roan antelope on $28^{\text {th }}$ July 1853 (near present-day Bethlehem in the Eastern Free State Province) were likely confused for blue antelope. Arbousset and Daumas (1846) list a host of bovids present in the area and mention that there are others yet unknown by name. It is thus possible that isolated small herds of Hippotragus survived in the region until the mid- $19^{\text {th }}$ century, but without more robust evidence remains difficult to confirm.

Other notable (rare) species documented include the Cape or bat-eared fox, Temminck's pangolin and wild dog. Wild dog were only reported on two occasions, which implies that they were only occasional visitors to the region. In 1834, Smith observed them near the Phuthiatsana River, while Maeder reported a pack near Beerseba in 1842:

"...grass was very luxuriant, particularly near the Putehazan (Phuthiatsana) River, upon which we encamped for the night. Near one of the herds of elands in which were one or two calves, a small troop of wild dogs were loitering about and immediately they discovered us and fled."

(Kirby, 1839, p136) 
In 1842, Maeder reports sightings of various species including 'foxes' and 'jackals', which implies that either Cape or bat-eared foxes were present in the region:

"The hare, the armadillo and the sagoumes and the surittates make themselves seen by their acute cries [.......] when one reaches sandy places, one sees traces of lions, panthers, wolves, foxes, hyenas, jackals and wild dogs."

(PEMS AA FBN 69. Maeder, F. Bérseba. $1^{\text {er }}$ Octobre 1842)

Although it is not clear what species the name 'sagoumes' may represent, it can be assumed that 'armadillo' are Temminck's pangolin (based on descriptive species' similarities and there not having been the name 'pangolin' during the time of observation) and 'surittates' are suricate. Today pangolin only occur in the drier northwestern and northern regions of South Africa, but isolated $20^{\text {th }}$ century records from areas near the Lesotho border have been documented (Pietersen et al., 2016). Pangolin are rare, nocturnal and mostly solitary mammals that inhabit semi-arid to mesic savannas at low population densities (Pietersen et al. 2014, 2020). The isolated report from the $19^{\text {th }}$ century is thus not surprising. However, none of the species discussed above are mentioned after the mid- $19^{\text {th }}$ century, so either became regionally extinct or remained in very low numbers.

\subsection{The oral history record (ca AD 1900 to present)}

The $20^{\text {th }}$ century faunal record of Lesotho has been documented previously in publications such as Mapetla (1969) and Ambrose (2006). We consider this literature and combine it with new evidence from our 58 oral interviews, ad hoc interviews and personal observations to update the status of larger mammals for the $20^{\text {th }}$ and early $21^{\text {st }}$ centuries (Table 3 ).

The only large antelope to survive into the $20^{\text {th }}$ century in Lesotho were common eland and red hartebeest. However, by 1906 eland had already become very scarce in the mountains (Ambrose, 2006) and likely soon thereafter became regionally extinct; only the parents/ grandparents of elderly interviewees recalled seeing either species. According to Skead (1987), by 1915 an estimated 500-700 red hartebeest survived along the high Drakensberg plateau, particularly between Sani Pass and Giant's Castle (Fig. 1), but a blizzard in 1918 killed the remaining herds. However, a few individuals are thought to have survived the blizzard, with the last hartebeest killed by dogs in 1925 (Vinnicombe 1976) - this ended the wild ranging of larger antelope in Lesotho. Reintroductions of black wildebeest and eland to Sehlabathebe and Tsehlanyane National Parks respectively, have been of relatively poor success due mainly to poaching. However, eland still occur in a specially protected area of Tsehlanyane National Park and at times migrate from South Africa into the Sehlabathebe National Park. Although some interviewees recall former sightings of smaller antelope such as steenbok, common (grey) duiker and red duiker, there were no recent confirmed sightings, and thus these, together with the Cape grysbok (last seen during the $19^{\text {th }}$ century), are now considered locally extinct. The only remaining small antelope are grey rhebok (most widespread and common), mountain reedbuck, common reedbuck, oribi and klipspringer - all of which are now restricted to more protected high mountain refugia and should thus be considered as threatened. Common 
reedbuck and oribi are likely only occasional visitors from neighbouring South African protected areas (e.g. Maloti-Drakensberg Park).

The only large predators reported during the $20^{\text {th }}$ century are leopard and brown hyaena. Three interviewees recall seeing leopards in their youth: one of which was already dead (in ca 1922), another which had been killed after having attacked a herder in the Mokhotlong region (in ca 1936), and the most recent one killed in the Makhaleng Valley (in the late 1970s/early 1980s). In addition, Ambrose (2006) reports a more recent sighting at Makatseng in 1993. Although not confirmed, vagrant leopards may still occasionally make opportunistic appearances along border regions of Lesotho. In contrast, the last brown hyaena was killed at Sekubu in 1970 and no further sightings have been documented or confirmed through interviews since then. Sightings of middle-sized carnivores were only reported for caracal by two interviewees, while none remembered seeing serval. Although thought locally extinct for several decades (Ambrose 2006), serval were recently (last 10 years) poached in the Sehlabathebe and Tsehlanyane National Parks (personal communication with park officials and personal observations - see Figure 6a), while aardwolf and honey badgers were last recorded in the lowlands during the 1950s (Ambrose 2006).

Of the smaller carnivores, black-backed jackal, African wild cat and slender mongoose are regularly seen in all regions of Lesotho (Table 3). African wild cat are sometimes partially domesticated and seen amongst the rural homesteads (Figure 6b). Interestingly, most interviewees recognized slender mongoose and confirmed their continued existence, yet none identified small grey mongoose. Personal observations by SG confirm the occurrence of slender mongoose even at $3000 \mathrm{~m}$ a.s.l. in the Mokhotlong region. Eleven interviewees confirm having seen striped polecat (zorilla) in recent times, and one of us (SG) found a dead specimen in an alpine wetland at $2950 \mathrm{~m}$ a.s.l. in 2013. Other varieties of small carnivores have only been seen by one to three interviewees in recent decades, and are critically endangered, if not already locally extinct in most regions of Lesotho; these include the Cape clawless otter, small spotted genet, striped (white-naped) weasel, yellow mongoose and water mongoose (see Table $3)$.

The last confirmed sightings of aardvark date back to 1968 and 1983 but the species may still be present in isolated localities of western Lesotho (Ambrose, pers com.). Amongst the interviewees, there is no memory of bushpig and Temminck's pangolin, which must now be considered locally extinct. The somewhat more versatile southern African porcupine and southern African hedgehog are still very occasionally sighted (including personal sightings of the former). Finally, a few troops of chacama baboon survive in mountain refugia, particularly along the Maloti and Thaba-Putsoa Ranges; however, many interviewees commented on their numbers having declined substantially during the last few decades and not having seen them in recent years.

It would thus seem that another major pulse of regional mammalian extinctions occurred during the late $19^{\text {th }} /$ early $20^{\text {th }}$ century (common eland, red hartebeest, steenbok, bushpig, springhare, Temmick's pangolin, suricate, honey badger, aardwolf). The last few decades may also have witnessed the final sightings of leopard, brown hyaena, aardvark and common duiker. Many 
of the remaining larger- to mid-sized mammals are either threatened or faced with imminent local/regional extinction and survive only in mountain refugia or protected areas (chacama baboon, Cape clawless otter, caracal, serval, Natal red rock rabbit, mountain reedbuck, grey rhebok, oribi, klipspringer).

\section{Discussion and conclusions}

The biological significance of Lesotho stems from its dominantly high elevation and mountainous topography with large altitudinal and topographic variability. Importantly, this has produced climatic diversity and extremity, and in particular represents a region of secure water provision to fauna, even when surrounding regions are faced with extreme drought. Consequently, Lesotho, both past and present, has hosted diverse vegetation belts and plant communities within a relatively small geographic region, varying from semi-arid to temperate grasslands, Afro-montane shrublands and grasslands, forest niches (e.g. bamboo, Podocarpus), and southern Africa's only true alpine grasslands (see Carbutt and Edwards, 2015). It is thus unsurprising that Lesotho and surrounding regions have hosted a diverse and large number of wild faunal taxa during the late Quaternary - and that portions of this landscape have served as a regional biological edge, refugia zones and biogeographic corridors for wild mammals. We elaborate on such biological concepts and how they are pertinent to understanding species' occurrence/disappearance in Lesotho.

Some 61 large- to medium-sized mammalian taxa have been recorded in the Lesotho region during the last ca 14000 years. Remarkably, most species recorded through the Holocene were documented by the first European settlers during the first half of the $19^{\text {th }}$ century. Exceptions include the roan antelope, blue buck, blue duiker, red duiker, warthog, vervet monkey and hippopotamus - these became regionally extinct during the last few hundred years, but prior to the 1820s. Such species require select habitat conditions, and thus their extinctions in the region are likely a product of habitat change induced by climate and/or the arrival of huntergatherers and herders. What might be considered as disharmonious faunas locally coexisted throughout much of the Holocene and recent historical period. For instance, warthog and roan antelope (which favour open grass-woodland savannahs) occurred in Lesotho alongside mountain reedbuck and klipspringer (which favour rocky mountain grassland habitats) - this demonstrates steep (micro-) habitat gradients and dynamic habitat variability within a relatively small spatial context (few $\mathrm{km}$ ). In addition, given the substantial altitudinal and topographic variability, periods of climate change during the Holocene may not have induced dramatic local-scale changes in ecology, but rather promoted elevational/topographic shifts in microhabitats (i.e. vegetation and ecological communities), as has also been reported for the mountains of New Guinea (e.g. Hope, 2014) and the Andes (e.g. Larsen et al., 2011). Consequently, no major mammalian extinction or colonization events are recorded in the Lesotho region during the Holocene, prior to the arrival of hunter-gatherers and herders (Esterhuysen and Mitchell, 1996). 
Many of the antelope species were seasonal (late spring-summer-early autumn) migrants to the Lesotho region. Springbok (Boer settlers called these 'trek-bokken' - wandering/migrating antelopes) in the Cape colony would migrate (together with plains zebra and wildebeest in particular) from the western and southwestern regions of southern Africa towards Lesotho during spring (Boshoff et al., 2016)(Fig. 7a). The huge migrations were part of a cycle of rainfall and reproduction, with periods of abundant rains resulting in enormous springbok population expansion (Roche, 2004), thus making it necessary to migrate for grazing replenishment. These springbok (and other migrant mammals) did not continue eastwards of the Great Escarpment in the Lesotho region, most likely given the formidable topographic barrier. In fact, the western Lesotho mountain front (Maloti and Thaba Putsoa Ranges) would have served as a biogeographic habitat edge to several species (Fig. 7a). For migrants from the drier western regions (e.g. springbok, blue wildebeest, zebra), the area would have represented their habitat edge.

The dramatic decline in wildlife populations and local species extinctions in the Lesotho region during the period ca AD 1840-1870 is strongly associated with the expansion of European settlement in the central interior of southern Africa. Human population expansion led to: a) extensive disruption to migratory herd development in areas considerably distant to Lesotho; b) grazing resource competition between wild and domestic fauna; c) major hunting campaigns throughout the former Cape Colony and Lesotho region; and d) associated land occupation and land use changes (Fig. 7b).

European settlement and sheep farming, with associated fencing, rapidly expanded over the central interior of southern Africa during the $19^{\text {th }}$ century; this restricted animal movement and, together with the extensive hunting campaigns, brought the great migrations to an end. Although the last springbok migration occurred during the extreme drought of 1896 (Roche, 2004; Nash and Grab, 2010; Neukom et al., 2014; Nash et al., 2016), there is no mention that it reached Lesotho. By 1884 it was reported that '[springbok] can no longer be found in Lesotho [......] they have all travelled north and are never to be seen. In a place where animals are always killed they cannot live together with man and so they leave' (Lesinyana la Lesotho, 1884, vol 6). According to Germond (1967), several factors impacted on hunting during the $19^{\text {th }}$ century, some of which we mention here. Otter and leopard skins were sought after by Zulu warriors, while pelts of leopard, hyaena and lion were exclusively reserved for the King (Moshoeshoe) at that time. Animal products were used for trade (especially pelts) and witchcraft (especially the tails of black wildebeest and the blood of red hartebeest), while the meat of common eland was favoured by missionaries and the Basotho. Although such hunting is likely to have been sustainable in earlier decades of the $19^{\text {th }}$ century, it became less so once the settlers became involved in commercial hunting campaigns, which, according to Cassalis, resulted in up to several hundred hunters assembling in the evenings. As early as 1834, Andrew Smith reports that "the appearance of large herds of quaggas (Equus Burchelli) called forth a large party of hunters....." (Kirby, 1939; p55). However, true shotguns were only available and in common use from the 1850 s onwards, followed by breech loading (i.e. from the back of the barrel) weaponry from the early1860s onwards. During the same time, horses became locally more readily available, which improved hunting mobility. Human population expansion in the 
Lesotho region had escalated by the early 1860s. At this time, Thaba-Nchu is said by Lemue to have had 'ten thousand inhabitants... piled up on top of the other'; he also mentions that Boer settler farms were 'here and there', having 'altered everything', and were the cause for the demise of wildlife (Germond, 1967; p457). Hence, the dual impact of rapidly expanding settlement and the introduction of hunting weaponry from the 1850s onwards were likely to have promoted an exponential impact on the extirpation of wild fauna. Trade records indicate that several hundred thousand hides were being exported from the Colony each year by the 1870s (Boshoff and Kerley, 2013).

The last two decades of the $19^{\text {th }}$ century became one of dynamic survival tactics for mammals, in part due to the regional biological edge effects, but also as a result of the biogeographic corridors through which species had moved in relative safety now becoming increasingly restricted. Given the surrounding topography of escarpment walls, the main biogeographic corridors into the mountain grazing regions of central Lesotho would have been through major drainage basins (Fig. 7c). The corridors along western Lesotho would have been largely occupied by human settlement by the end of the $19^{\text {th }}$ century, when villages spread into the mountain forelands. According to the newspaper Leselinyana la Lesotho (15 July 1897), some animals were still grazing in the Maloti mountains and these likely accessed the last remaining corridors in southern Lesotho where any form of seasonal migration still existed (i.e. through the Makhaleng and Senqu River Valleys). The newspaper report mentions that in 1895 and 1897, leopards were killed at Sengoto and Moyeni regions respectively. The leopard killed in 1897 had apparently taken many sheep, goats and horses and so it was felt that killing it was justice served. In addition, a serval was killed in 1896, also in the Moyeni region. Through topographic refugia in the mountainous landscape, regional extinction debt may have been prolonged for leopard and the more reclusive, nocturnal carnivores such as brown hyaena and aardwolf, but these are all now considered locally extinct.

By the turn of the century, almost all larger mammals had become locally extinct, with a few exceptions including common eland, red hartebeest, chacama baboon and leopard. Those species remaining (including the several smaller varieties of antelope and carnivores) had retreated into the mountains (which served as a regional refugia) and were essentially surrounded by an ever-encroaching human population. The last surviving herds of red hartebeest in the Lesotho highlands served as an extralimital population, as the taxa had become regionally extinct in surrounding lowlands but endured prolonged survival in mountain refugia at their habitat edge. According to Yackulic et al. (2011), mammal populations at the edge of the species' range are likely to have lower growth rates and are most vulnerable to extirpation. Although the central Lesotho mountains offered an adequate refugial size, the harsh winter climate was not suitable for red hartebeest and common eland. With biological corridors now restricted for seasonal migration (Fig. 7c), these last herds of eland and hartebeest eventually succumbed to climatic and anthropogenic pressures.

Yackulic et al. (2011) demonstrate that surviving mammalian edge populations are more vulnerable than those near the core of their range. To this end, smaller antelopes such as grey rhebok and klipspringer have fared best and continue to survive, together with chacama baboon, Natal red rock rabbits and a variety of smaller carnivores (e.g. mongoose; African wild 
cat) in what are now fragmented mountain refugia. However, given that patch area and isolation (connectivity or non-connectivity) between patches are important factors affecting remnant populations and their long-term survival (Prugh et al., 2008), these remaining isolated populations are increasingly threatened, particularly as their refugial habitat continues to decline spatially and the distance between refugial patches continues to grow. According to Keppel et al. (2012), defining refugia sites or regions requires a globally applicable framework, yet with parameters that are identified for specific regional scenarios. Wildlife refugia may encompass areas of safety from human pressures, landscape or landcover change, or climate change. The Lesotho mountain region offered the last remaining large mammals a macro-scale refuge (Fig. 7c). However, while offering a refuge against human and landcover pressures, it conflictingly presented detrimental exposure to extreme climatic conditions.

Life-history traits of given species will strongly determine their responses when faced with habitat change and isolation (Öckinger et al., 2010). Species with low mobility, narrow feeding niches (e.g. bushbuck - long extinct to Lesotho) or specialized topographic requirements (e.g. Klipspringer) have been/will be most strongly affected by habitat loss, climate change and other pressures. Many of the last surviving wild faunal taxa in Lesotho are doing so at their habitat edge, in isolated micro-scale refugia, and without interconnecting biogeographic corridors. Thus, without urgent management and conservation intervention, the long history of what was once a richly diverse fauna in Lesotho and surrounding regions is fast approaching its end.

\section{Acknowledgements}

This research was funded by British Academy Small Grant SG-40838. We thank the Département Français pour l'Action Apostolique, Council for World Mission for permission to use quotations. We thank Dr David Ambrose for sharing his insights and knowledge with us. Puleng Morake is thanked for assistance with oral interviews and Sesotho language translations. Dr Stephanie Mills kindly assisted with the analysis of Paris Evangelical Missionary Society materials and provided French to English language translations, which are much appreciated. Many thanks to the two anonymous reviewers and guest editor who provided valuable suggestions that have helped improve the manuscript.

\section{References}

Ambrose, D., 2006. Lesotho Annotated Bibliography: Mammals (2md Edition). House 9 Publications, University of Lesotho.

Arbousset, T., 1991. Missionary excursion into the Blue Mountains, being an account of King Moshoeshoe's expedition from Thaba-Bosiu to the sources of the Malibamatso River in the year 1840 (edited and translated by Ambrose D and Brutsch A). Morija Archives, Morija (unpublished manuscript). 
Arbousset, T., Daumas, F., 1968. Narrative of an exploratory tour to the north-east of the Colony of the Cape of Good Hope. Struik, Cape Town.

Arthur, C., Mitchell, P., Dewar, G., Badenhorst, S., 2018. After the silt: middle and late Holocene hunter-gatherer archaeology of the Metolong Dam, Lesotho. S.A. Humanities 31, 129-179.

Avenant, N.L., 1997. Mammals recorded in the QwaQwa National Park (1994-1995). Koedoe $40,31-40$.

Avenant, N.L. 2006. Mammal Report, Maloti Drakensberg Transfrontier Park Biodiversity Assessment. Contract GEF/002. Maloti Drakensberg Ecology Consultants, Maseru.

Aybes, C., Yalden, D.W., 1995. Place-name evidence for the former distribution and status of wolves and beavers in Britain. Mammal Rev. 25, 201-226.

Badenhorst, S., Mitchell, P.J., Arthur, C., Capelli, C., 2019. Late Holocene fauna from Moshebi's Shelter, a Later Stone Age site in Lesotho. S.A. Humanities 32, 83-107.

Blaum, N., Rossmanith, E., Popp, A., Jeltsch, F., 2007. Shrub encroachment affects mammalian carnivore abundance and species richness in semiarid rangelands. Acta Oecologica, 31, 86-92.

Bellard, C., Cassey, P., Blackburn, T.M., 2016. Alien species as a driver of recent extinctions. Biol. Letters 12, 20150623.

Brown, A.J.V., Verhagen, Th., 1985. Two Antidorcas bondi individuals from the Late Stone Age site of Kruger Cave 35/83, Olifantsnek, Rustenburg District, South Africa. S.A. Jnl. Sci. $81,102$.

Boshoff, A., Kerley, G., 2013. Historical Incidence of the Larger Mammals in the Free State Province (South Africa) and Lesotho. Centre for African Conservation Ecology, Port Elizabeth.

Boshoff, A., Landman, M., Kerley, G., 2016. Filling the gaps on the maps: historical distribution patterns of some larger mammals in part of southern Africa. Trans. Royal Soc. S.A. 71, 23-87.

Bunn, H.T., 1982. Meat-eating and human evolution: studies on the diet and subsistence patterns of Plio-Pleistocene hominids in East Africa. Unpublished PhD thesis. Berkley, University of California, Berkley.

Burbidge, A.A., Johnson, K.A., Fuller, P.J., Southgate, R.I., 1988. Aboriginal knowledge of the mammals of the Central Deserts of Australia. Aust. Wildlife Res. 15, 9-39.

Broom, R., 1949. The extinct blue buck of South Africa. Nature 164, 1097-1098.

Carbutt, C., Edwards, T.J., 2015. Reconciling ecological and phytogeographical spatial boundaries to clarify the limits of the montane and alpine regions of sub-Sahelian Africa. S.A. Jnl. Bot. 98, 64-75. 
Ceballos, G., Garcia, A., Ehrlich, P.R., 2010. The sixth extinction crisis: loss of animal populations and species. Jnl. Cosmol. 8, 1821-1831.

Ceballos, G., Ehrlich, P.R., Dirzo, R., 2017. Biological annihilation via the ongoing sixth mass extinction signaled by vertebrate population losses and declines. Proc. Nat. Acad. Sci. 114, E6089-E6096.

Codron, D., Brink, J.S., 2007. Trophic ecology of two savanna grazers, blue wildebeest Connochaetes taurinus and black wildebeest Connochaetes gnou. Euro. Jnl. Wildlife Res. 53, 90-99.

Colahan, B.D., 1990. Did the last blue antelope Hippotragus leucophaeus die in the eastern Orange Free State, South Africa? S.A. Jnl. Sci. 86, 477-478.

Cooke, H.B.S., 1963. Pleistocene mammal faunas of Africa, with particular reference to southern Africa, in: Howell, F.C., Boulière, F., (Eds.), African Ecology and Human Evolution, Aldine, Chicago, pp. 65-116.

Davidson, A.D., Hamilton, M.J., Boyer, A.G., Brown, J.H., Ceballos, G., 2009. Multiple ecological pathways to extinction in mammals. PNAS 106, 10702-10705.

Discamps, E., Jaubert, J., Bachellerie, F., 2011. Human choices and environmental constraints: deciphering the variability of large game procurement from Mousterian to Aurignacian times (MIS 5-3) in southwestern France. Quat. Sci. Rev. 30, 2755-2775.

Du Preez, P.J., Breedenkamp, G.J., 1991. Vegetation classes of the southern and eastern Orange Free State (Republic of South Africa) and the highlands of Lesotho. Navorsinge Nas Mus. Bloem. 7, 477-526.

Engela, R., 1995. Space, material culture and meaning in the Late Pleistocene and early Holocene at Rose Cottage Cave. MA thesis, University of the Witwatersrand, Johannesburg.

Esterhuysen, A.B., Mitchell, P.J., 1996. Palaeoenvironmental and archaeological implications of charcoal assemblage from Holocene sites in western Lesotho, southern Africa. Palaeoecol. Afr. Surrounding Isl. 24, 203-232.

Faith, J.T., Thompson, J.C., 2013. Fossil evidence for seasonal calving and migration of extinct blue antelope (Hippotragus leucophaeus) in southern Africa. Jnl. Bio. Geog. 40, 2108-2118.

Fitchett, J., Grab, S.W., Bamford, M., Mackay, A., 2016. A multi-proxy analysis of late Quaternary palaeoenvironments, Sekhokong Range, eastern Lesotho. Jnl. Quat. Sci. 31, 788798.

Fitchett, J., Mackay, A., Grab, S.W., Bamford, M., 2017. Holocene climatic variability indicated by a multi-proxy record from southern Africa's highest wetland. Holocene 27, 638650 .

Frick, W.F., Pollock, J.F., Hicks, A.C., Langwig, K.E., Reynolds, D.S., Turner, G.G., Butchkoski, C.M., Kunz, T.H., 2010. An emerging disease causes regional population collapse of a common North American bat species. Sci. 329, 679-682. 
Germond, R.C., 1967. Chronicles of Basutholand: A running commentary on the events of the years 1830-1902 by the French missionaries in southern Africa. Morija Sesotho Book Depot, Lesotho.

Gortázar, C., Herrero, J., Villafuerte, R., Marco, J., 1998. Historical examination of the status of large mammals in Aragon, Spain. Mammalia 64, 411-422.

Grab, S.W., Nash, D.J., 2010. Documentary evidence of climate variability during cold seasons in Lesotho, southern Africa, 1833-1900. Clim. Dyn. 34, 473-499.

Grab, S.W., Knight, J., 2016. Glacial and periglacial geomorphology, in: Knight, J., Grab, S.W., (Eds.), Quaternary Environmental Change in Southern Africa. Cambridge University Press, Cambridge, pp. 121-136.

Grab, S.W., Scott, L., Rossouw, L., Meyer, S., 2005. Holocene palaeoenvironments inferred from a sedimentary sequence in the Tsoaing River Basin, western Lesotho. Catena 61, 49-62.

Grab, S.W., Linde, J., De Lemos, H., 2017. Some attributes of snow occurrence and snowmelt / sublimation rates in the Lesotho Highlands: environmental implications. Water SA 43, 333-342.

Grogan, L.F., Berger, L., Rose, K., Grillo, V., Cashins, S.D., Skerratt, L.F., 2014. Surveillance for emerging biodiversity diseases of wildlife. PLOS Pathogens 10: e1004015.

Hofmeyer, I., 1993. "We spend our years as a tale that is told": Oral Historical Narrative in a South African Chiefdom. James Currey, London.

Hope, G., 2014. The sensitivity of the high mountain ecosystems of New Guinea to climatic change and anthropogenic impact. Arctic, Antarctic, Alp. Res. 46, 777-786.

Hough, C., 2008. Deer in Sussex place-names. The Antiquaries Jnl. 88, 43-47.

Hydén, L., 2002. The influence on summer rainfall in the Lesotho lowlands from Indian Ocean SSTs. Nordic Hydrol. 33, 305-318.

Kay, C., Bredenkamp, G.J., Theron, G.K., 1993. Plant communities of the Golden Gate Highlands National Park. S.A. Jnl. Bot. 59, 442-449.

Keppel, G., Van Niel, K.P., Wardell-Johnson, G.W., Yates, C.J., Byrne, M., Mucina, L., Schut, A.G.T., Hopper, S.D., Franklin, S.E., 2012. Refugia: identifying and understanding safe havens for biodiversity under climate change. Global Ecol. Biogeog. 21, 393-404.

Kerley, G.I., Sims-Castley, R., Boshoff, A.F., Cowling, R.M., 2009. Extinction of the blue antelope Hippotragus leucophaeus: modeling predicts non-viable global population size as the primary driver. Biodiv. Conserv. 18, 3235.

Kirby, P.R., 1939. The diary of Dr Andrew Smith. Van Riebeeck Society, vol 1, Cape Town. 
Kirby, P.R., 1965. Sir Andrew Smith, MD, KCB: his life, letters and works. Balkema, Rotterdam.

Klein, R.G., 1974. On the taxonomic status, distribution and ecology of the blue antelope, Hippotragus leucophaeus (Pallas, 1766). Annals S.A. Mus. 65, 99-143.

Klein, R.G. 1979. Stone Age exploitation of animals in southern Africa. American Sci. 67, 151-160.

Klein, R.G., Criz-Uribe, K., 1987. Large mammal and tortoise bones from Eland's Bay Cave and nearby sites, western Cape Province, South Africa, in: Parkington, J.E., Hall, M. (Eds.), Papers in the Prehistory of the Western Cape, pp. 132-163. British Archaeological Reports, Oxford.

Larsen, T.H., Brehm, G., Navarrete, H., Franco, P., Gomez, H., Mena, J.L., Morales, V., Argollo, J., Blacutt, L., Canhos, V., 2011. Range shifts and extinctions driven by climate change in the tropical Andes: synthesis and directions, in: Herzog, S.K., Tiessen, H., (Eds.), Climate change and biodiversity in the tropical Andes, IAI, Scope, Chicago, pp. 47-67.

Lett, S.C., 1970. An analysis of Navajo place-names. Names 18, 175-184.

Loubser, J., Brink, J., Laurens, G., 1990. Paintings of the extinct blue antelope, Hippotragus leucophaeus, in the eastern Orange Free State. S. A. Arch. Bull. 45, 106-111.

Lynch, C.D., 1994. The mammals of Lesotho. Navorsinge Nas. Mus. Bloem. 10, 177-241.

Mapetla, J., 1969. Liphoofolo, linonyana, litaola le lithoko tsa tsona. Morija Sesuto Book Depot, Morija.

Marker, M.E., 1995. Late Quaternary environmental implications from sedimentary sequences at two high altitude Lesotho sites. S.A. Jnl. Sci. 91, 294-298.

Mills, S.C., Grab, S.W., Carr, S.J., 2009. Recognition and palaeoclimatic implications of Late Quaternary niche glaciation in eastern Lesotho. Jnl Quat. Sci. 24, 647-663.

Mills, S.C., Grab, S.W., Rea, B.R., Carr, S.C., Farrow, A., 2012. Shifting westerlies and precipitation patterns during the Late Pleistocene in southern Africa determined using glacier reconstruction and mass balance modelling. Quat. Sci. Rev. 55, 145-159.

Mitchell, P.J., 1993. Archaeological investigations at two Lesotho rock-shelters: terminal Pleistocene/early Holocene assemblages from Ha Makotoko and Ntloana Tsoana. Proc. Prehistoric Soc. 59, 39-60, Cambridge University Press.

Mitchell, P.J., 1996. The late Quaternary of the Lesotho highlands, southern Africa: preliminary results and future potential of ongoing research at Sehonghong Shelter. Quat. Int. 33, 35-44.

Mitchell, P.J., Parkington, J., Wadley, L., 1998. A tale from three regions: the archaeology of the Pleistocene/Holocene transition in the Western Cape, the Caledon Valley and the Lesotho highlands, southern Africa. Quat. Int. 49/50, 105-115. 
Monsarrat, S., Kerley, G.I.H., 2018. Charismatic species of the past: biases in reporting of large mammals in historical written sources. Biol. Cons. 223, 68-75.

Nash, D.J., Grab, S.W., 2010. "A sky of brass and burning winds": Documentary evidence of rainfall variability in the kingdom of Lesotho, southern Africa, 1824-1900. Clim. Change 101, 617-653.

Nash, D.J., Pribyl, K., Klein, J., Neukom, R., Endfield, G.H., Adamson, G.C.D., Kniveton, D.R., 2016. Seasonal rainfall variability in southeast Africa during the nineteenth century reconstructed from documentary sources. Clim. Change 134, 605-619.

National Environment Secretariat, 2000. Biological Diversity in Lesotho: A Country Study. Ministry of Environment, Maseru.

Nersting, L.G., Arctander, P., 2001. Phylogeography and conservation of impala and greater kudu. Molecular Ecol. 10, 711-719.

Neukom, R., Nash, D.J., Endfield, G.H., Grab, S.W., Grove, C., Kelso, C., Vogel, C.H., Zinke, J., 2014. Multi-proxy summer and winter precipitation reconstruction for southern Africa over the last 200 years. Clim. Dyn. 42, 2713-2726.

Öckinger, E., Schweiger, O., Crist, T.O., Debinski, D.M., Krauss, J., Kuussaari, M., Petersen, J.D., Pöyry, J., Settele, J., Summerville, K.S., Bommarco, R., 2010. Life-history traits predict species responses to habitat area and isolation: a cross-continental synthesis. Ecol. Letters 13, 969-979.

Pietersen, D.W., McKechnie, A. E., Jansen, R., 2014. Home range, habitat selection and activity patterns of an arid-zone population of Temminck's ground pangolins, Smutsia temminckii. Afr. Zool. 49, 265-276.

Pietersen, D.W., Jansen, R., Swart, J., Kotze, A., 2016. A conservation assessment of Smutsia temminckii, in: Child, M.F., Roxburgh, L., Do Linh San, E., Raimondo, D., Davies-Mostert, H.T. (Eds.), The Red List of Mammals of South Africa, Swaziland and Lesotho. South African National Biodiversity Institute and Endangered Wildlife Trust, South Africa.

Pietersen, D.W., Jansen, R., Swart, J., Panaino, W., Kotze, A., Rankin, P., Nebe, B., 2020. Temminck’s pangolin Smutsia temminckii. Pangolins, Academic Press, pp. 175-193.

Plug, I., 1997. Late Pleistocene and Holocene Hunter-Gatherers in the Eastern Highlands of South Africa and Lesotho: A faunal interpretation. Jnl Archaeol. Sci. 24, 715-727.

Plug, I., Engela, R., 1992. The macrofaunal remains from recent excavations at Rose Cottage Cave, Orange Free State. S.A. Archaeol. Bull. 47, 16-25.

Plug, I., Mitchell, P.J., 2008. Sehonghong: hunter-gatherer utilization of animal resources in the highlands of Lesotho. Annals Transvaal Mus. 45, 31-53. 
Plug, I., Mitchell, P.J., Bailey, G., 2003. Animal remains from Likoaeng, an open-air river site, and its place in the post-classic Wilton of Lesotho and eastern Free State, South Africa. S.A. Jnl. Sci. 99, 143-152.

Prugh, L.R., Hodges, K.E., Sinclair, A.R.E., Brashares, J.S., 2008. Effect of habitat area and isolation on fragmented animal populations. PNAS 105, 20770-20775.

Roche, C.J., 2004. "Ornaments of the Desert": Springbok Treks in the Cape Colony, 17741908. MA thesis, University of Cape Town, Cape Town.

Scott, L., Nyakale, M., 2002. Pollen indications of Holocene palaeoenvironments at Florisbad spring in the central Free State, South Africa. Holocene 12, 497-503.

Scott, L., Neumann, F.H., Brook, G.A., Bousman, C.B., Norström, E., Metwally, A.A., 2012. Terrestrial fossil-pollen evidence of climate change during the last 26 thousand years in southern Africa. Quat. Sci. Rev. 32, 100-118.

Sene, K.J., Jones, D.A., Meigh, J.R., Farquharson, F.A.K., 1998. Rainfall and flow variations in the Lesotho Highlands. Int. Jnl. Clim. 18, 329-345.

Si, A., Agnihotri, S., 2014. Solega place names and their ecological significance. Anthropol. Linguistics 56, 389-414.

Skead, C.J., 1987. Historical Mammal Incidence in the Cape Province (Eastern Half of the Cape Province), vol 2. Chief Directorate of Nature and Environmental Conservation, Cape Town.

Skinner, J.D., Chimimba, C.T., 2005. The Mammals of the Southern African Sub-region $-3^{\text {rd }}$ Edition. Cambridge University Press, Cambridge.

Smith, J.M., Lee-Thorp, J.A., Sealy, J.C., 2002. Stable carbon and oxygen isotope evidence for late Pleistocene and early-middle Holocene climatic fluctuations in the Caledon River Valley, southern Africa. Jnl. Quat. Sci. 17, 683-696.

Stewart, B.A., Mitchell, P.J., 2018. Late Quaternary palaeoclimates and human-environment dynamics of the Maloti-Drakensberg region, southern Africa. Quat. Sci. Rev. 196, 1-20.

Stuart, C., Stuart, T., 2001. Field Guide to the Mammals of Southern Africa. Struik, Cape Town.

Themudo, E.G., Campos, P.F., 2017. Phylogenetic position of the extinct blue antelope, Hippotragus leucophaeus (Pallas, 1766)(Bovidae: Hippotraginae), based on complete mitochondrial genomes. Zoolog. Jnl. Linnean Soc. 182, 225-235.

Tsujino, R., Ishimaru, E., Yumoto, T., 2010. Distribution patterns of five mammals in the Jomon period, middle Edo period, and the present, in the Japanese Archipelago. Mammal Study $35,179-189$.

Vinnicombe, P., 1976. People of the Eland. University of Natal Press, Pietermaritzburg. 
Von Richter, W., 1972. Remarks on present distribution and abundance of some South African carnivores. S.A. Jnl Wildlife Res. 2, 9-16.

Wadley, L., 2000. The Wilton and pre-ceramic Wilton industries at Rose Cottage Cave and their context in the South African sequence. S.A. Archaeol. Bull. 55, 90-106.

Wilson, R.T., 2012. The biological exploration of Darfur, 1799-1998. Archiv. Nat. Hist. 39, 39-58.

Wolf, C., Ripple, W.J., 2016. Prey depletion as a threat to the world's large carnivores. Royal Soc. Open Sci. 3, 160252.

Yackulic, C.B., Sanderson, E.W., Uriarte, M., 2011. Anthropogenic and environmental drivers of modern range loss in large mammals. PNAS 108, 4024-4029.

Zielinski, W.J., Truex, R.L., Schlexer, F.V., Campbell, L.A., Carroll, C., 2005. Historical and contemporary distributions of carnivores in forests of the Sierra Nevada, California, USA. Jnl. Biogeog. 32, 1385-1407. 


\section{Figures:}

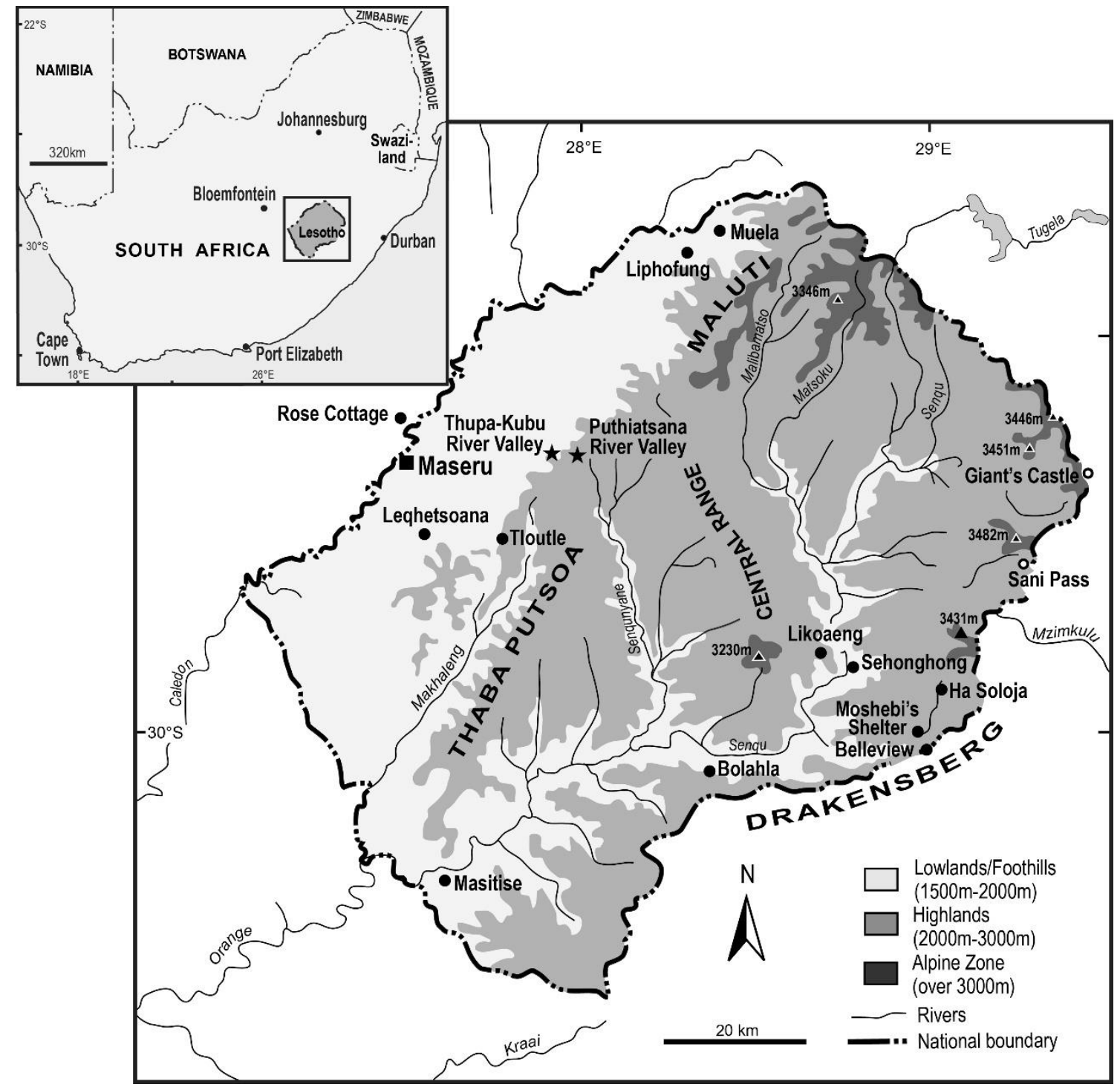

Figure 1: Lesotho and the surrounding study region, indicating the regional topographic setting and archaeological sites from which published past faunal information was obtained. 


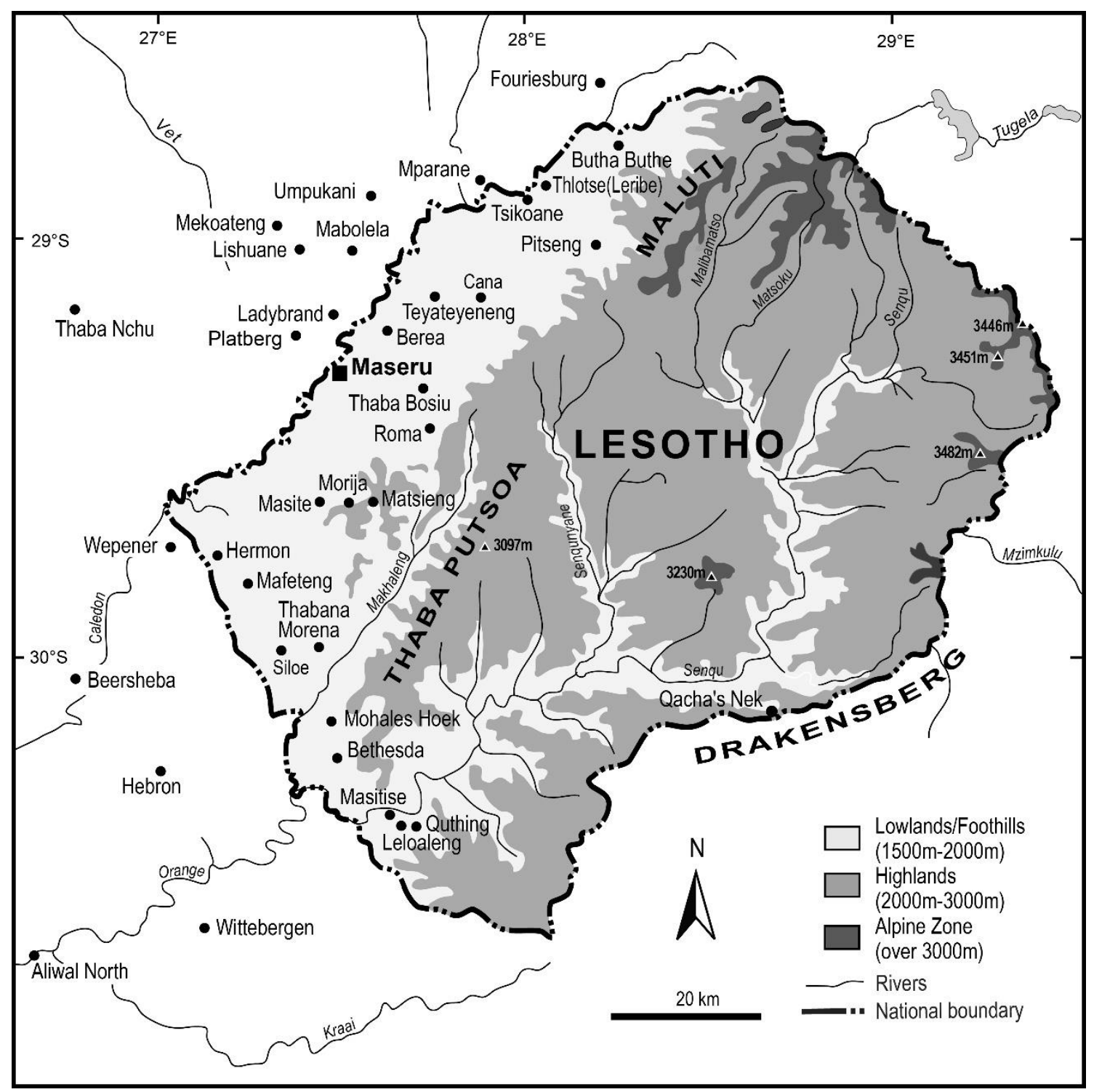

Figure 2: Study region, indicating missionary stations from which $19^{\text {th }}$ century documentary-based faunal information was obtained. 


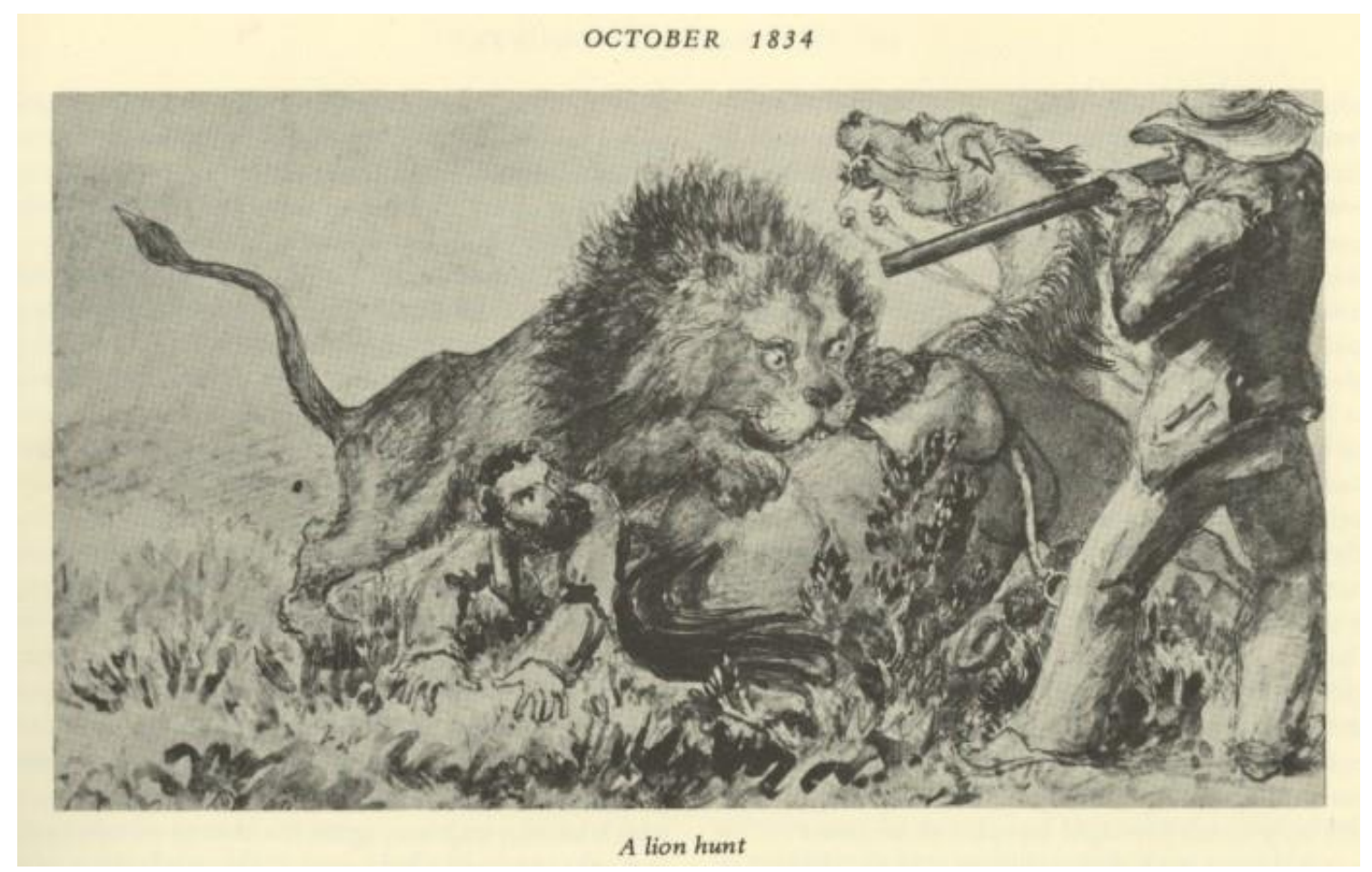

Figure 3: Sketch by naturalist and explorer, Andrew Smith, depicting a lion hunt in the Lesotho region in 1834 (source, Kirby, 1965, p55). 


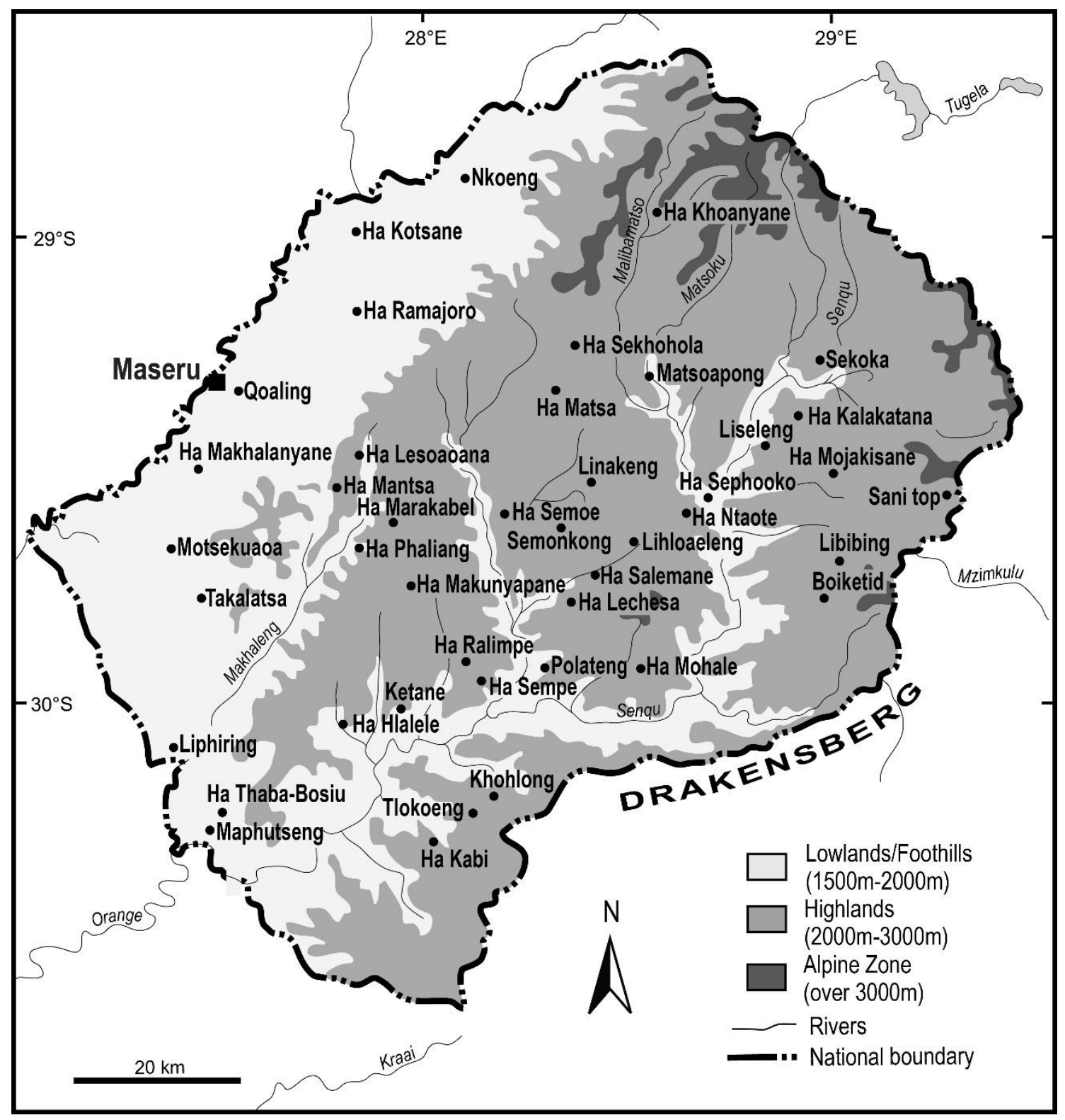

Figure 4: Study region, indicating villages in which oral interviews took place in 2008. 


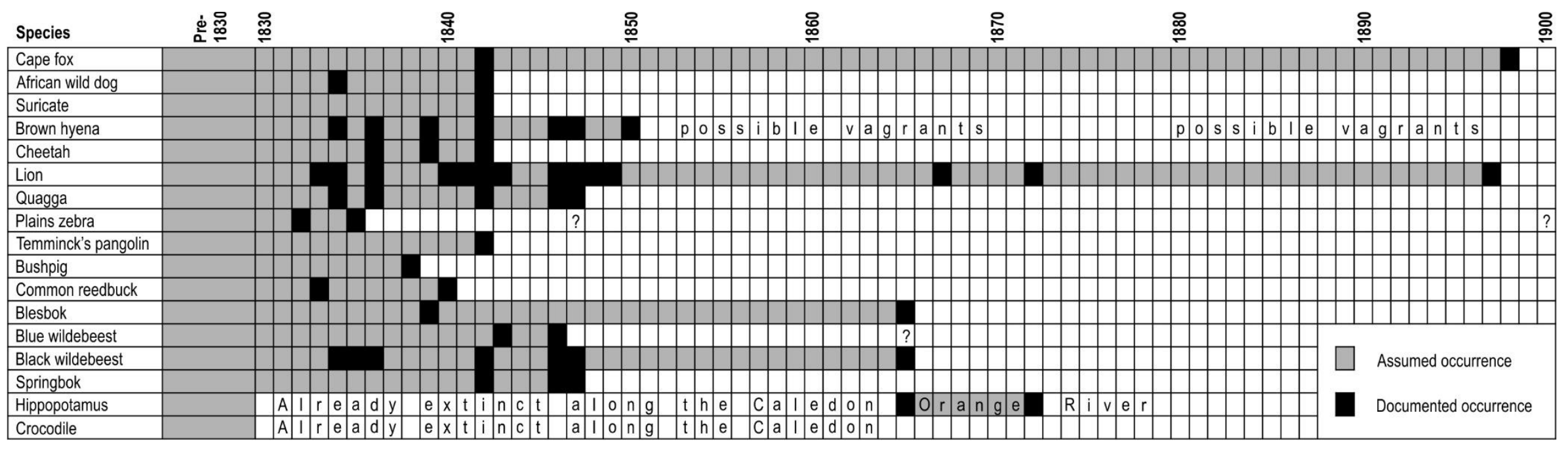

Figure 5: Mammalian species extinctions during the $19^{\text {th }}$ century in Lesotho and adjoining regions to the west and south (records are based on documentary evidence). 

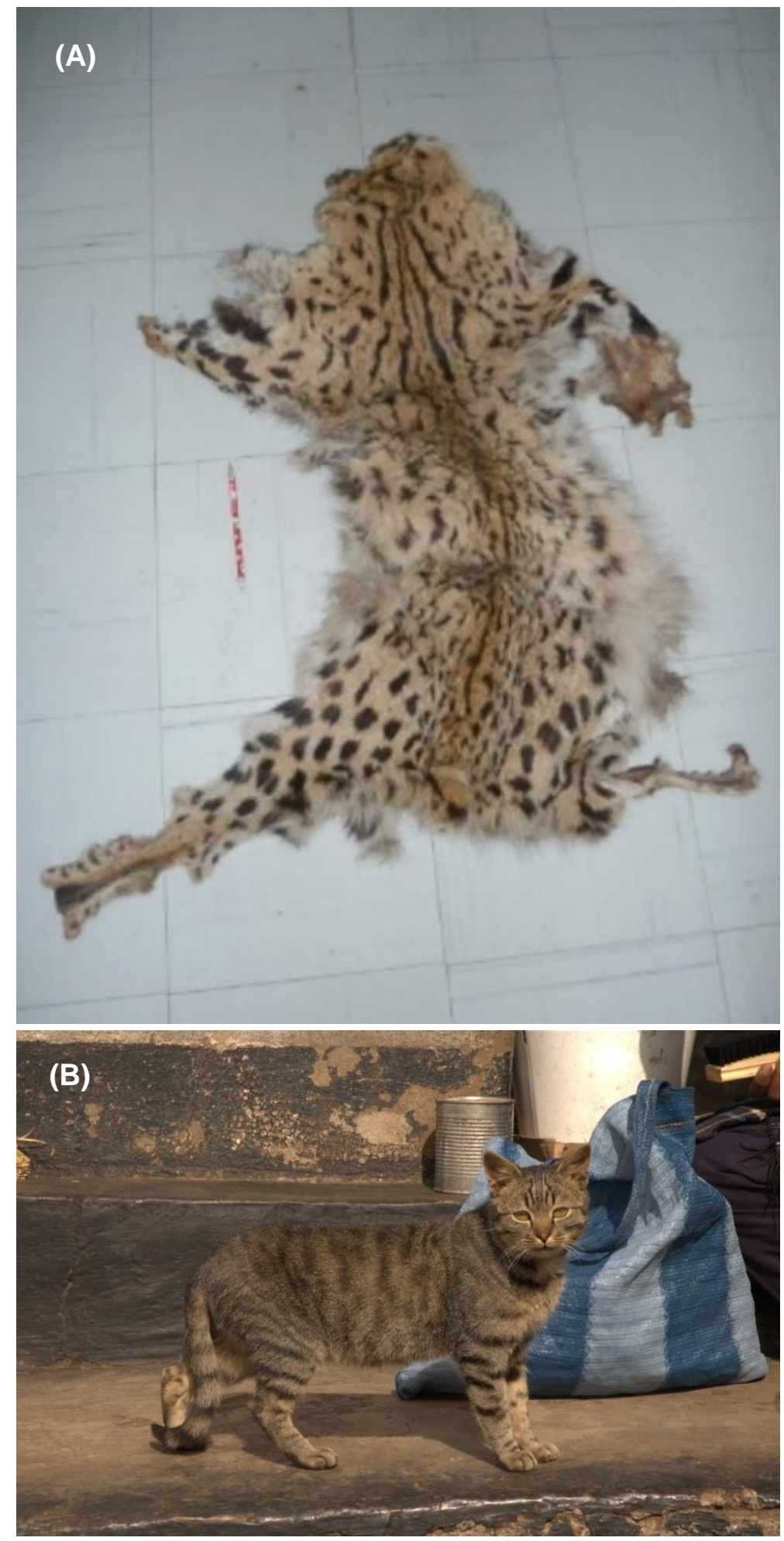

Figure 6: a) Skin of a serval that had been poached in the Sehlabathebe National Park in 2013, and b) a domesticated African wild cat in a Lesotho highlands village in 2014 (photos: S. Grab). 
Pre 1830: Spring migration
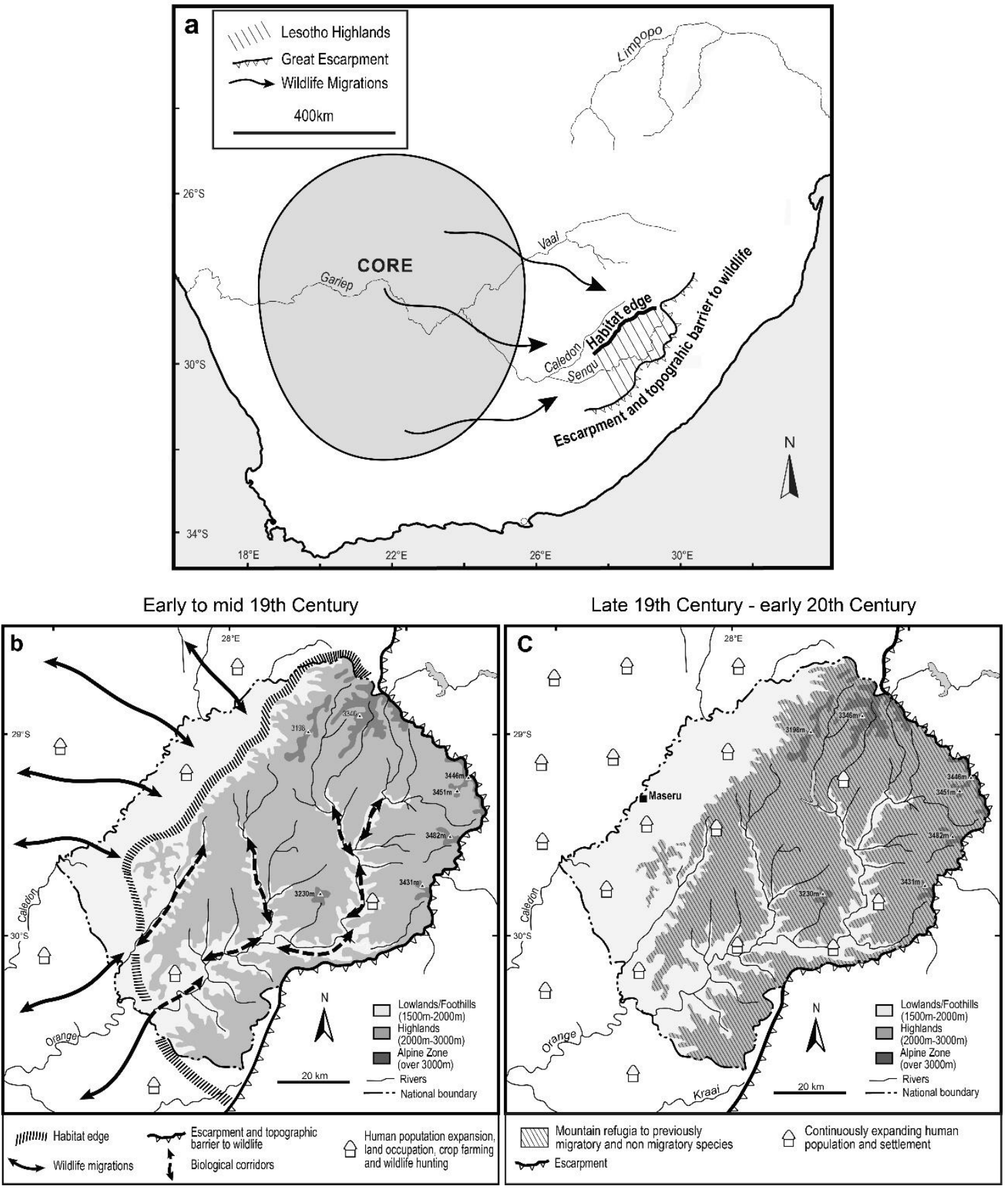

Figure 7: a) Wildlife migrations in the sub-continent prior to the 1830s; b) regional dynamics influencing early to mid $19^{\text {th }}$ century wildlife migrations and movements in the Lesotho region, and the c) late $19^{\text {th }}$ to early $20^{\text {th }}$ century situation in which wildlife had retreated into mountain refugia. 
Tables

\begin{tabular}{|l|l|c|}
\hline Sesotho Place Name & Animal & $\begin{array}{l}\text { Number of } \\
\text { localities }\end{array}$ \\
\hline Taung & Place of the lion & 4 \\
\hline Nkoeng & Place of the leopard & 2 \\
\hline Mangaung & Place of cheetahs & 1 \\
\hline Makanyaneng & Place of the African wild dog & 1 \\
\hline Liphiring & Place of the brown hyaena & 3 \\
\hline Phokojoe-khoaba & Place of Jackals & 1 \\
\hline Liseleng & Place of the honey badger & 1 \\
\hline Liphofung & Place of the eland & 5 \\
\hline Manamaneng & Place of the eland calf & 1 \\
\hline Likhameng & Place of the red hartebeest & 4 \\
\hline Lihloaeleng & Place of oribis & 1 \\
\hline Thaba Likome & Mountain of the Klipspringer & 1 \\
\hline Quacha's Nek & Quagga (the neck of) & 1 \\
\hline Lithakaleng & Place of the Aardvark & 1 \\
\hline Lokolobeng & Place of the wild pig & 1 \\
\hline Litsoeneng & Place of the baboon & 9 \\
\hline Likoeneng & Place of the crocodile & 2 \\
\hline
\end{tabular}

Table 1: Sesotho places named (villages, mountains, rivers) after mammals. 


\begin{tabular}{|c|c|c|c|c|c|c|c|c|c|}
\hline \multirow[b]{2}{*}{ Common names } & \multirow{2}{*}{ 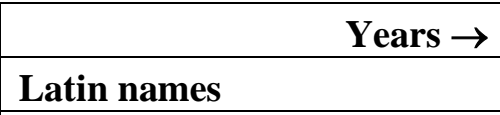 } & \multicolumn{2}{|c|}{ 14-10K BP } & \multicolumn{2}{|c|}{ 10-5K BP } & \multicolumn{2}{|c|}{ 5-3K BP } & \multicolumn{2}{|c|}{ Last 3K } \\
\hline & & $\mathbf{L}$ & F/H & $\mathbf{L}$ & F/H & $\mathbf{L}$ & $\mathbf{F} / \mathbf{H}$ & $\mathbf{L}$ & $\mathbf{F} / \mathbf{H}$ \\
\hline Chacama baboon & Papio cynocephalus ursinus & $\mathrm{X}$ & $X$ & $\mathrm{X}$ & $\mathrm{X}$ & $\mathrm{X}$ & $\mathrm{X}$ & $\mathrm{X}$ & $\mathrm{X}$ \\
\hline Vervet monkey & Cercopithecus aethiops & & & $\mathrm{X}$ & & $\mathrm{X}$ & $X$ & $\mathrm{X}$ & $X$ \\
\hline Plains zebra & Equus burchellii & $X$ & $X$ & $\mathrm{X}$ & $\mathrm{X}$ & & $X$ & $X$ & $\mathrm{X}$ \\
\hline Cape zebra (Quagga) & Equus quagga quagga & $\mathrm{X}$ & $\mathrm{X}$ & $\mathrm{X}$ & & & $\mathrm{X}$ & & \\
\hline Rock hyrax & Procavia capensis & & $X$ & $\mathrm{X}$ & $\mathrm{X}$ & $\mathrm{X}$ & $X$ & $\mathrm{X}$ & $X$ \\
\hline Hare/rabbit & Lepus saxatilis/capensis & & $X$ & $\mathrm{X}$ & $X$ & $\mathrm{X}$ & $X$ & $X$ & $X$ \\
\hline $\begin{array}{l}\text { Smith's red rock } \\
\text { rabbit }\end{array}$ & Pronolagus rupestris & & & & & & & $\mathrm{X}$ & \\
\hline Springhare & Pedetes capensis & $\mathrm{X}$ & & $\mathrm{X}$ & $\mathrm{X}$ & & $\mathrm{X}$ & $\mathrm{X}$ & $\mathrm{X}$ \\
\hline Aardvark & Orycteropus afer & & & & & & $\mathrm{X}$ & & \\
\hline Southern porcupine & Hystrix africaeaustralis & & $\mathrm{X}$ & $X$ & $\mathrm{X}$ & $\mathrm{X}$ & $\mathrm{X}$ & $\mathrm{X}$ & $X$ \\
\hline $\begin{array}{l}\text { Southern ground } \\
\text { squirrel }\end{array}$ & Xerus inauris & & & & $\mathrm{X}$ & & $\mathrm{X}$ & $\mathrm{X}$ & $\mathrm{X}$ \\
\hline Warthog & Phacochoerus africanus & $\mathrm{X}$ & & $\mathrm{X}$ & $X$ & $\mathrm{X}$ & $X$ & $\mathrm{X}$ & $\mathrm{X}$ \\
\hline Bushpig & Potamochoerus larvatus & & & & & & & $\mathrm{X}$ & $X$ \\
\hline $\begin{array}{l}\text { Common (grey) } \\
\text { duiker }\end{array}$ & Sylvicapra grimmia & & $\mathrm{X}$ & $X$ & & & $\mathrm{X}$ & $\mathrm{X}$ & $\mathrm{X}$ \\
\hline Blue duiker & Cephalophus monticola & & & & $\mathrm{X}$ & & & $\mathrm{X}$ & \\
\hline Red duiker & Cephalophus natalensis & & & & & & & & $X$ \\
\hline Oribi & Ourebia ourebi & & $\mathrm{X}$ & & $\mathrm{X}$ & & $\mathrm{X}$ & $\mathrm{X}$ & $\mathrm{X}$ \\
\hline Steenbok & Raphicerus campestris & & $\mathrm{X}$ & $\mathrm{X}$ & $\mathrm{X}$ & $\mathrm{X}$ & $\mathrm{X}$ & $\mathrm{X}$ & $\mathrm{X}$ \\
\hline Grey rhebok & Pelea capreolus & & $X$ & $X$ & $X$ & $\mathrm{X}$ & $X$ & $X$ & $X$ \\
\hline Mountain reedbuck & Redunca fulvorufula & $\mathrm{X}$ & $\mathrm{X}$ & $X$ & $X$ & $\mathrm{X}$ & $\mathrm{X}$ & $\mathrm{X}$ & $\mathrm{X}$ \\
\hline Common reedbuck & Redunca arundinum & & & & & & $\mathrm{X}$ & & $\mathrm{X}$ \\
\hline Klipspringer & Oreotragus oreotragus & & $\mathrm{X}$ & $\mathrm{X}$ & $\mathrm{X}$ & $\mathrm{X}$ & $\mathrm{X}$ & $\mathrm{X}$ & $\mathrm{X}$ \\
\hline Bushbuck & Tragelaphus scriptus & & $\mathrm{X}$ & & & & & & \\
\hline Impala & Aepyceros melampus & & & & i & & & $\mathrm{X}$ & \\
\hline Black wildebeest & Connochaetes gnou & $\mathrm{X}$ & $\mathrm{X}$ & $\mathrm{X}$ & $\mathrm{X}$ & $\mathrm{X}$ & $\mathrm{X}$ & $\mathrm{X}$ & $\mathrm{X}$ \\
\hline Blue wildebeest & Connochaetes taurinus & & & $\mathrm{X}$ & & & & $\mathrm{X}$ & $\mathrm{X}$ \\
\hline Red hartebeest & Alcelaphus buselaphus caama & $\mathrm{X}$ & $\mathrm{X}$ & $\mathrm{X}$ & $\mathrm{X}$ & $\mathrm{X}$ & $\mathrm{X}$ & $\mathrm{X}$ & $\mathrm{X}$ \\
\hline Giant hartebeest & Megalotragus priscus & $\mathrm{X}$ & & & & & & & \\
\hline Blesbok & Damaliscus dorcas & $\mathrm{X}$ & $\mathrm{X}$ & $\mathrm{X}$ & & $\mathrm{X}$ & $\mathrm{X}$ & $\mathrm{X}$ & $\mathrm{X}$ \\
\hline Springbok & Antidorcas marsupialis & $\mathrm{X}$ & $\mathrm{X}$ & $X$ & $\mathrm{X}$ & $\mathrm{X}$ & $\mathrm{X}$ & $\mathrm{X}$ & $\mathrm{X}$ \\
\hline Bond's springbok & Antidorcas bondi & $\mathrm{X}$ & & $\mathrm{X}$ & & & & & \\
\hline Roan antelope & Hippotragus equinus & $\mathrm{X}$ & $\mathrm{X}$ & & & $\mathrm{X}$ & & & $\mathrm{X}$ \\
\hline Blue antelope & Hippotragus leucophaeus & $\mathrm{X}$ & $\mathrm{X}$ & $\mathrm{X}$ & $\mathrm{X}$ & & & & \\
\hline Greater kudu & Tragelaphus strepsiceros & & & $\mathrm{X}$ & & & & & \\
\hline Common eland & Tragelaphus oryx & $\mathrm{X}$ & $\mathrm{X}$ & $\mathrm{X}$ & $\mathrm{X}$ & $\mathrm{X}$ & $\mathrm{X}$ & $\mathrm{X}$ & $\mathrm{X}$ \\
\hline Tortoise & possibly Homopus femoralis & & & & & $\mathrm{X}$ & $\mathrm{X}$ & & $X$ \\
\hline Water mongoose & Atilax paludinosus & & & $\mathrm{X}$ & $\mathrm{X}$ & & & $\mathrm{X}$ & $\mathrm{X}$ \\
\hline Yellow mongoose & Cynictis penicillata & & & & & & & $\mathrm{X}$ & \\
\hline White tailed mongoose & Ichneumia albicauda & & & & & & $\mathrm{X}$ & & \\
\hline Mongoose (unknown) & & & $X$ & & & & $X$ & & $X$ \\
\hline $\begin{array}{l}\text { Striped polecat } \\
\text { (Zorilla) }\end{array}$ & Ictonyx striatus & & & & & & & & $X$ \\
\hline Suricate (meerkat) & Suricata suricatta & & & & & $\mathrm{X}$ & & & \\
\hline
\end{tabular}




\begin{tabular}{|l|l|l|l|l|l|l|l|l|l|}
\hline Genet or weasel ? & & & $\mathrm{X}$ & $\mathrm{X}$ & $\mathrm{X}$ & $\mathrm{X}$ & $\mathrm{X}$ & $\mathrm{X}$ & \\
\hline Cape clawless otter & Aonyx capensis & & & & & $\mathrm{X}$ & & & $\mathrm{X}$ \\
\hline Black-backed jackal & Canis mesomelas & & $\mathrm{X}$ & $\mathrm{X}$ & $\mathrm{X}$ & $\mathrm{X}$ & $\mathrm{X}$ & $\mathrm{X}$ & $\mathrm{X}$ \\
\hline Cape fox & Vulpes chama & & & & & & & $\mathrm{X}$ & $\mathrm{X}$ \\
\hline Aardwolf & Proteles cristatus & & & & & & $\mathrm{X}$ & & \\
\hline Brown hyaena & Hyaena brunnea & & likely & & $\mathrm{X}$ & & & $\mathrm{X}$ & $\mathrm{X}$ \\
\hline Wild dog & Lycaon pictus & & & & & & & & \\
\hline $\begin{array}{l}\text { Dog (possibly wild } \\
\text { dog) }\end{array}$ & & & & & & & $\mathrm{X}$ & & $\mathrm{X}$ \\
\hline Honey Badger & Mellivora capensis & & & & & & & & \\
\hline Lion & Panthera leo & & & $\mathrm{X}$ & & $\mathrm{X}$ & $\mathrm{X}$ & $\mathrm{X}$ & $\mathrm{X}$ \\
\hline Leopard & Panthera pardus & & & & & & & & \\
\hline Cheetah & Acinonyx jubatus & & & & & & & & \\
\hline Serval & Leptailurus serval & & $\mathrm{X}$ & & & $\mathrm{X}$ & $\mathrm{X}$ & $\mathrm{X}$ & $\mathrm{X}$ \\
\hline Caracal & Caracal caracal & & & & & $\mathrm{X}$ & $\mathrm{X}$ & $\mathrm{X}$ & $\mathrm{X}$ \\
\hline African wild cat & Felis silvestris & & & & \\
\hline
\end{tabular}

Table 2: Late Pleistocene (ca 14000 yrs BP) to late Holocene (ca 150 yrs BP) mammalian species occurrence in the Lesotho and adjacent western regions, based on published* archaeo-faunal records ( $\mathrm{L}=$ lowlands/forelands; $\mathrm{F} / \mathrm{H}=$ foothills/highlands). *after Engela (1995); Plug and Engela (1992); Plug (1997); Wadley (2000); Plug et al. (2003); Plug and Mitchell (2008); Arthur et al. (2018); Badenhorst et al. (2019). 


\begin{tabular}{|c|c|c|c|c|}
\hline Common name & Latin name & $\begin{array}{c}\text { Remembered } \\
\text { historically }\end{array}$ & $\begin{array}{l}\text { Still } \\
\text { seen }\end{array}$ & Notes \\
\hline Chacama baboon & Papio cynocephalus ursinus & & $\mathrm{X}$ & Few troops remaining, mostly along mountain ranges \\
\hline Rock hyrax & Procavia capensis & & $\mathrm{X}$ & Widespread \\
\hline Hare & Lepus saxatilis/capensis & & $\mathrm{X}$ & Widespread but low numbers \\
\hline Natal red rock rabbit & Pronolagus crassicaudatus & & $\mathrm{X}$ & Isolated to a few high mountain summits \\
\hline Springhare & Pedetes capensis & $\mathrm{X}$ & & No confirmed sightings, current status = 'locally extinct' \\
\hline Aardvark & Orycteropus afer & $\mathrm{X}$ & & Confirmed sightings only in $1968 \& 1983$, current status = 'locally extinct \\
\hline Temminck's pangolin & Manis temmincki & $\mathrm{X}$ & & No confirmed sightings, current status = 'locally extinct' \\
\hline Southern African hedgehog & Atelerix frontalis & & $\mathrm{X}$ & Widespread but very rare \\
\hline Southern porcupine & Hystrix africaeaustralis & & $\mathrm{X}$ & Isolated sightings \\
\hline Southern ground squirrel & Xerus inauris & $\mathrm{X}$ & & No confirmed sightings, current status = 'locally extinct' \\
\hline Bushpig & Potamochoerus larvatus & $\mathrm{X}$ & & Last sightings in the $1930 \mathrm{~s}$, current status = 'locally extinct' \\
\hline Common (grey) duiker & Sylvicapra grimmia & $\mathrm{X}$ & & No confirmed sightings, current status = 'locally extinct' \\
\hline Red duiker & Cephalophus natalensis & $\mathrm{X}$ & & No confirmed sightings, current status = 'locally extinct' \\
\hline Oribi & Ourebia ourebi & & $\mathrm{X}$ & Isolated sightings in protected ares (e.g. Sehlabathebe National Park) \\
\hline Steenbok & Raphicerus campestris & $\mathrm{X}$ & & No confirmed sightings, current status = 'locally extinct' \\
\hline Cape Grysbok & Raphicerus melanotis & $\mathrm{X}$ & & No confirmed sightings, current status = 'locally extinct' \\
\hline Grey rhebok & Pelea capreolus & & $\mathrm{X}$ & Widespread occurrence, numbers declining, restricted to mountain refugia \\
\hline Mountain reedbuck & Redunca fulvorufula & & $\mathrm{X}$ & Few small groups remain in mountain refugia \\
\hline Common reedbuck & Redunca arundinum & & $\mathrm{X}$ & Isolated sightings in protected areas (e.g. Sehlabathebe National Park) \\
\hline Klipspringer & Oreotragus oreotragus & & $\mathrm{X}$ & Few small groups remain in Drakensberg mountain refugia \\
\hline Red hartebeest & Alcelaphus buselaphus caama & $\mathrm{X}$ & & Last antelope killed by dogs in 1925 \\
\hline Common eland & Tragelaphus oryx & & $\mathrm{X}$ & Reintroduced to a few mountain protected areas \\
\hline Genet & Genetta tigrina & & $\mathrm{X}$ & Rare, one confirmed recent sighting in the Mokhotlong region \\
\hline Water mongoose & Atilax paludinosus & & $\mathrm{X}$ & Very rarely seen \\
\hline Yellow mongoose & Cynictis penicillata & & $\mathrm{X}$ & Still occurs in the Mafeteng - Berea regions \\
\hline Slender mongoose & Galerella sanguinea & & $\mathrm{X}$ & Widespread \\
\hline Striped polecat (zorilla) & Ictonyx striatus & & $\mathrm{X}$ & Still widespread \\
\hline Striped weasel & Poecilogale albinucha & & $\mathrm{X}$ & Confirmed sighting from Mokhotlong region \\
\hline Suricate (meerkat) & Suricata suricatta & $\mathrm{X}$ & & Current status = 'locally extinct' \\
\hline Cape clawless otter & Aonyx capensis & & $\mathrm{X}$ & Rare, critically endangered in Lesotho \\
\hline Black-backed jackal & Canis mesomelas & & $\mathrm{X}$ & Still widespread \\
\hline Cape fox & Vulpes chama & $X$ & $?$ & Rare, possibly restricted to Quthing region \\
\hline Aardwolf & Proteles cristatus & $\mathrm{X}$ & & Infrequent vagrants may still be possible in the western/southern lowlands \\
\hline Honey badger & Mellivora capensis & $\mathrm{X}$ & & Still possible pre-1950s, current status = 'locally extinct' \\
\hline
\end{tabular}




\begin{tabular}{|l|l|c|c|l|}
\hline Leopard & Panthera pardus & $\mathrm{X}$ & $?$ & Infrequent vagrants/killings recorded through the 20th C \\
\hline Serval & Leptailurus serval & & $\mathrm{X}$ & Rare, likely restricted to Maloti and Drakensberg ranges \\
\hline Caracal & Caracal caracal & & $\mathrm{X}$ & Rare, very occasional/infrequent sightings in the highlands \\
\hline African wild cat & Felis silvestris & & $\mathrm{X}$ & Widespread \\
\hline Small spotted cat & Felis nigripes & $\mathrm{X}$ & & One unconfirmed sighting only \\
\hline
\end{tabular}

Table 3: Status of mammalian occurrences in Lesotho and adjoining regions (to the west and south) during the last ca 110 years (records based on oral histories, documentary records and personal observations). 